\title{
Functional Groups and Pore Size Distribution Do Matter to Hierarchically Porous Carbons as High Rate Performance Supercapacitors
}

\author{
Xianjun Wei*, Xiaoqiang Jiang, Jishi Wei, Shuyan Gao* \\ Collaborative Innovation Center of Henan Province for Green Manufacturing of Fine Chemicals, Key Laboratory \\ of Green Chemical Media and Reactions (Ministry of Education), School of Chemistry and Chemical Engineering, \\ Henan Normal University, Xinxiang 453007, China
}




\section{Experimental Section:}

The specific capacitance $\left(C_{g}\right)$ of a single electrode for three-electrode cell was determined by Eq. $\mathrm{S} 1:^{\left[\mathrm{S}_{1}\right]}$

$$
C_{g}\left(F g^{-1}\right)=2 \times \frac{I \times t}{V \times m}
$$

where I is the discharge current (A), $\mathrm{t}$ is the discharge time $(\mathrm{s}), \mathrm{V}$ is the potential change in discharge $(\mathrm{V})$ and $\mathrm{m}$ is the mass of the active material in a single electrode $(\mathrm{g})$.

The specific capacitance $\left(C_{g}\right)$ of a single electrode for two-electrode cell was determined by Eq. $\mathrm{S}_{2}:^{\left[\mathrm{S}_{2}\right]}$

$$
C_{g}\left(F g^{-1}\right)=4 \times \frac{I \times t}{V \times m}
$$

where I is the discharge current $(\mathrm{A}), \mathrm{t}$ is the discharge time $(\mathrm{s}), \mathrm{V}$ is the potential change in discharge $(\mathrm{V})$ and $\mathrm{m}$ is the total mass of the active material in both electrodes $(\mathrm{g})$.

The energy density, $\mathrm{E}\left(\mathrm{Wh} \mathrm{kg}^{-1}\right)$, and the average power density, $\mathrm{P}\left(\mathrm{W} \mathrm{kg}{ }^{-1}\right)$, of supercapacitor are calculated on the basis of Eq. $\mathrm{S}_{3}{ }^{\left[\mathrm{S}_{2}\right]}$ and Eq. $\mathrm{S}_{4} \cdot{ }^{\left[{ }_{3}, \mathrm{~S}_{4}\right]}$

$$
\begin{aligned}
& \boldsymbol{E}=\frac{\boldsymbol{C}}{8 \times 3.6} \boldsymbol{V}^{2} \\
& \boldsymbol{P}=\frac{\boldsymbol{I} \times \boldsymbol{V}}{2 \boldsymbol{m}}
\end{aligned}
$$

where $C$ is the capacitance of the two-electrode capacitor $(F), V$ is the voltage decrease or the usable voltage (V) excluding the IR drop occurring at the discharge beginning, $\mathrm{I}$ is the current and $\mathrm{m}$ the total mass of two working electrodes.

EIS analysis: In general, an impedance spectrum contains a depressed semicircle at high frequency followed by a $45^{\circ}$ inclination and a nearly vertical line at low frequency. The resistance at very high frequency range is bulk electrolyte resistance in solution and interfacial resistance between the current collector and electrodes, denoted as $R_{s}$. As the frequency decreases, a depressed semicircle appears and its diameter represents the semicircle resistance, $R_{c t}$, which includes various resistive factors such as electrode porosity and the charge transfer resistance of 
possible pseudocapacity. We introduced constant phase element ZCPE1, which is described as Eq. $\mathrm{S}_{5}$ instead of capacitor element, to investigate the deformed semicircle. ${ }^{\left[\mathrm{S}_{5}, \mathrm{~S} 6\right]}$

$$
\text { ZCPE } 1=\frac{1}{Q_{1}}(j)^{n_{1}}
$$

In Nyquist plot, a $45^{\circ}$ sloped line occurs, which is originated from the resistance, $Z_{\mathrm{p}}$, and expressed as Eq. S6, associated with the electrolyte penetration of the electrode pores.

$$
Z_{p}=R_{p} \frac{\tanh \left([j T \omega]^{p}\right)}{(j T \omega)^{p}}
$$

The Eq. S6 is the solution of the one-dimensional diffusion equation of a particle, which is completely analogous to wave transmission in a finite-length $\mathrm{RC}$ transmission line. $R_{\mathrm{p}}$ is total electrolyte diffusion resistance, $\mathrm{o}<\mathrm{p}<1$, and $\mathrm{T}=\mathrm{L}^{2} / \mathrm{D}$ ( $\mathrm{L}$ is the effective diffusion thickness, and $\mathrm{D}$ is the effective diffusion coefficient of the particle).

An ideal capacitor shows a vertical line at very low frequency region, but the inclined line is generally observed due to pseudocapacitive effect or non-uniform charging rate distribution. So, another constant phase element (expressed as Eq. $\mathrm{S}_{7}$ was employed to describe this line. ${ }^{\left[\mathrm{S}_{5}, \mathrm{~S}_{7}\right]}$

$$
\boldsymbol{Z C P E} 2=\frac{1}{Q_{2}}(j)^{\boldsymbol{n}_{2}}
$$

\section{Ar Adsorption/Desorption Isotherms and Pore Size Distributions}

PANI-6oo, PANI-70o, and PANI-8oo display Type II, and other (twenty-three) samples display Type I isotherm with a small hysteresis loop, showing the characteristic of microporous, mesopores or macroporous materials. The assembly of micropores, mesopores or macropores forms the hierarchical construction, which was verified by the MP pore size distribution (Figure 1b, S1c, S2c, S2d, S2e and S2f), and the textural features of PNPEA and PANI based carbons (sixteen samples) were summarized in Table 1 and Table S2. Without chemical activation, the BET surface area of PNPEA based carbon increases with the pyrolysis temperature and reaches $268.9 \mathrm{~m}^{2} \mathrm{~g}^{-1}$ at $600{ }^{\circ} \mathrm{C}$, $335.8 \mathrm{~m}^{2} \mathrm{~g}^{-1}$ at $700{ }^{\circ} \mathrm{C}$, and $403.8 \mathrm{~m}^{2} \mathrm{~g}^{-1}$ at $800{ }^{\circ} \mathrm{C}$, respectively. The surface area of PEA-Zn-70o 
increases sharply through $\mathrm{ZnCl}_{2}$ activation, with its value as high as $1030.6 \mathrm{~m}^{2} \mathrm{~g}^{-1}$, which is nearly three times as much as that of PEA-70o. PEA-Zn-70o possesses the highest BET surface area (1030.6 $\left.\mathrm{m}^{2} \mathrm{~g}^{-1}\right)$ and total pore volume $\left(0.5105 \mathrm{~cm}^{3} \mathrm{~g}^{-1}\right)$ among the samples synthesized in PNPEA based samples. The specific surface area and total pore volume of PNPEA based carbon activated by $\mathrm{ZnCl}_{2}$ decrease as the activation temperature increases from 700 to $800{ }^{\circ} \mathrm{C}$. Obviously, $\mathrm{ZnCl}_{2}$ and the pyrolysis temperature play an important role in the evolvement of pore structure. It is currently accepted that $\mathrm{ZnCl}_{2}$ acts as dehydration reagent and template, ${ }^{[\mathrm{S} 8]}$ and then promotes dehydration reactions of PNPEA at a lower pyrolysis temperature, which results in aromatization of the carbon skeleton and in turn generates a pore structure. Moreover, the spaces left by $\mathrm{ZnCl}_{2}$ after washing with $\mathrm{H}_{2} \mathrm{O}$ and $\mathrm{HCl}$ aqueous solution constitutes additional microporosity and mesoporosity in the internal structure of the carbonized sample. When the pyrolysis temperature increases beyond $800{ }^{\circ} \mathrm{C}, \mathrm{ZnCl}_{2}$ volatilizes out of the sample, and without the $\mathrm{ZnCl}_{2}$ particles to support the pore structure, the structural changes with heat treatment cause pore shrinkage and pore collapse, which leads to a decrease in the specific surface area, micropore and mesopore volumes. ${ }^{\left[\mathrm{S}_{3}\right]}$ When PEA-Zn700 is oxidized with mixed acid for $\mathrm{th}$ at different temperatures, its BET surface area drops from $1030.6 \mathrm{~m}^{2} \mathrm{~g}^{-1}$ to $781.2 \mathrm{~m}^{2} \mathrm{~g}^{-1}$ at $25{ }^{\circ} \mathrm{C}, 760.6 \mathrm{~m}^{2} \mathrm{~g}^{-1}$ at $40{ }^{\circ} \mathrm{C}, 723.3 \mathrm{~m}^{2} \mathrm{~g}^{-1}$ at $50{ }^{\circ} \mathrm{C}$ and $545.7 \mathrm{~m}^{2} \mathrm{~g}^{-1}$ at $60{ }^{\circ} \mathrm{C}$, respectively. Meanwhile, its micropore percentage decreases from $62.55 \%$ without oxidation to $51.15 \%$ oxidized at $60{ }^{\circ} \mathrm{C}$. In other word, mesopore percentage increases from $37.45 \%$ to $48.85 \%$. Surface oxygen complexes such as carboxyl, phenolic hydroxyl, lactone, and quinone could be formed on carbon when they are treated with mixed acid. The consequence of the oxygen complexes occupying the entrance of the pores may cause some of the micropores unaccessible to Ar molecule, and the oxidation may cause a partial structural collapse or widen the microporosity, resulting in a drop in both the surface area and pore volume. At different pyrolysis temperature with the same oxidation temperature, the surface area of PNPEA based carbons increases in this order, PEA-Zn-50o-40 $<$ PEA-Zn-60o-40 $<$ PEA-Zn-70o-40 $\leq$ PEA-Zn-80o-40, which is not the same as that of PANI based carbons. The surface area and pore volume of PEA-Zn-70o are higher than that of PANI-Zn-70o, and on the contrary, those of PEA-Zn-70o-40 are lower than those of PANI-Zn700-40. It is notable that the activation and oxidation have little influence on the average mesopore size of samples except PANI-7oo, but have significant effect on micropore size distribution (Figure 
Sic). PEA-70o shows a large peak at ca $0.56 \mathrm{~nm}$, a shoulder at ca $0.64 \mathrm{~nm}$, and a minor yet discernible broad peak in the approximate range of 1.04-2.0 nm. PEA-Zn-70o, the activated PEA700 through $\mathrm{ZnCl}_{2}$, whose micro-pore size distribution is remarkably different from that of the precursor, presents a large and broad peak in the range of $0.53^{-1.11} \mathrm{~nm}$, accompanying a small shoulder at $1.04 \mathrm{~nm}$, and minor peaks at ca $1.2 \mathrm{~nm}, 1.56 \mathrm{~nm}$, and $1.88 \mathrm{~nm}$. The oxidation products of PEA-Zn-70o at various temperatures show different micro-pore size distributions. PEA-Zn-70o-25 exhibits a dominant hump (a profile made by two adjoining and overlapping peaks) in the range of $0.56-0.96 \mathrm{~nm}$, the aforesaid shoulder at $1.04 \mathrm{~nm}$ and minor peak at ca $1.22 \mathrm{~nm}$ turn into a sharp peak, respectively, the peak at ca $1.56 \mathrm{~nm}$ turns into a small and broad peak in the range of 1.36-1.66 $\mathrm{nm}$, and the peak at ca $1.88 \mathrm{~nm}$ does not change. PEA-Zn-70o-40 and PEA-Zn-70o have almost the same pore size distribution below $2.0 \mathrm{~nm}$. When the oxidation temperature rises to $50{ }^{\circ} \mathrm{C}$, the large and broad peak in the rage of $0.53^{-1.11} \mathrm{~nm}$ changes into two large peaks (dominant) at ca $0.62 \mathrm{~nm}$ and $0.76 \mathrm{~nm}$, respectively, and the shoulder does not change. Further to improve the oxidation temperature to $60^{\circ} \mathrm{C}$, the large and broad peak is decomposed into three large peaks and a shoulder. The first is an intense peak at ca $0.56 \mathrm{~nm}$, partially overlapping with the second peak, and the second, the shoulder, and the third peak successively overlap with each other in the range of 0.61-1.04 nm, which grow into a fluctuant hill configuration.

For comparison, without chemical activation, the BET surface area of PANI based carbon increases with the pyrolysis temperature and reaches $400.3 \mathrm{~m}^{2} \mathrm{~g}^{-1}$ at $600{ }^{\circ} \mathrm{C}, 364.8 \mathrm{~m}^{2} \mathrm{~g}^{-1}$ at $700{ }^{\circ} \mathrm{C}$, and $172.8 \mathrm{~m}^{2} \mathrm{~g}^{-1}$ at $800{ }^{\circ} \mathrm{C}$, respectively. The surface area of PANI-Zn-70o increases sharply through $\mathrm{ZnCl}_{2}$ activation, with its value as high as $735.3 \mathrm{~m}^{2} \mathrm{~g}^{-1}$, which is nearly two times as much as that of PANI-70o. PANI-Zn-50o possesses the highest BET surface area $\left(1395.6 \mathrm{~m}^{2} \mathrm{~g}^{-1}\right)$ and total pore volume $\left(0.6508 \mathrm{~cm}^{3} \mathrm{~g}^{-1}\right)$ among the samples synthesized in this work. The specific surface area and total pore volume of PANI based carbon activated by $\mathrm{ZnCl}_{2}$ decrease as the activation temperature increases from 500 to $800{ }^{\circ} \mathrm{C}$, which does not include PANI-Zn-70o. When PANI-Zn-70o is oxidized with mixed acid for $1 \mathrm{~h}$ at different temperatures, its BET surface area drops from $735.5 \mathrm{~m}^{2} \mathrm{~g}^{-1}$ to $709.9 \mathrm{~m}^{2} \mathrm{~g}^{-1}$ at $25^{\circ} \mathrm{C}, 877 \mathrm{~m}^{2} \mathrm{~g}^{-1}$ at $40{ }^{\circ} \mathrm{C}, 706.4 \mathrm{~m}^{2} \mathrm{~g}^{-1}$ at $50^{\circ} \mathrm{C}$ and $404.7 \mathrm{~m}^{2} \mathrm{~g}^{-1}$ at $60{ }^{\circ} \mathrm{C}$, respectively. At different pyrolysis temperature with the same oxidation temperature, the surface area of PNPEA 
based carbons increases in this order, PANI-Zn-6oo-40 $<$ ANI-Zn-80o-40 $<$ ANI-Zn-70o-40. Figure S2c-f presents the variation of micropore size distributions of the samples with different pyrolysis or activation temperature and oxidation temperature. PANI-Zn-6oo exhibits a double-overlying and intense peak in the range of $0.56-76 \mathrm{~nm}$ overlapping a strong peak at ca $0.8 \mathrm{o} \mathrm{nm}$ and weak peak at ca 1.0 $\mathrm{nm}$. When PANI-Zn-6oo is oxidized at $40^{\circ} \mathrm{C}$, a large and broad peak appears in the range of 0.56-0.92 nm with two shoulders at ca 0.80 and $0.88 \mathrm{~nm}$, respectively, and a small peak exhibits at ca $1.0 \mathrm{~nm}$. On the contrary, oxidation dramatically alters the micropore size distribution of PANIZn-8oo, making a large and broad peak (in the range of $0.53^{-1.08} \mathrm{~nm}$ ) with a big shoulder (at ca $0.56 \mathrm{~nm}$ ) change into a sharp peak (at ca $0.60 \mathrm{~nm}$, dominant) and a small broad peak (in the range of $0.64-1.01 \mathrm{~nm})$. It should be noted that oxidation with mixed acid has different influence on the surface area and pore size distribution of PEA-Zn-70o and PANI-Zn-70o (see Figure 1a and 1b, Figure S1a-S1c, Figure S2a-2f, Table 1 and Table S2). For PEA-Zn-70o, its surface area and pore volume decrease after oxidation process, which indicates that oxidation transforms ultra-micropore to wider micropore and wider micropore to mesopore, thus reducing the number of micropores. For PANI-Zn-70o, its surface area and pore volume increase after oxidation. Oxidation develops wider micropore to ultra-micropores, see Figure S2d.

\section{Electrochemical test}

CV curves in three-electrode systems, as shown in Figure 2 and Figure $\mathrm{S}_{7}$, were recorded on CHI76oC electrochemical workstation (Chenhua, Shanghai, China) at the potential range of $0.8-0.2 \mathrm{~V}$ in acidic and neutral media and $-1-0 \mathrm{~V}$ or $-0.8-0.2 \mathrm{~V}$ in alkaline medium at the scan rate from 2 to $500 \mathrm{mV} \mathrm{s}^{-1}$. Charge/discharge versus time (Figure 3a, Figure S8a), specific capacitance versus discharge current density (Figure 3b, Figure S8b) and cycle life curves (Figure 3c, Figure S8c) were obtained from the galvanostatic charge/discharge tests on potentiostat/galvanostat (CT2001A, Land, Wuhan, China) and electrochemical workstation (CHI66oE and $\mathrm{CHI} 76 \circ \mathrm{C}$, Chenhua, Shanghai, China) at the same potential range (-0.8-0.2 V in acidic medium) by varying the current densities from 0.2 to $30 \mathrm{~A} \mathrm{~g}^{-1}$. The data about the specific capacitance $\left(C_{g}\right)$ of a single electrode was obtained through charge/discharge test at the potential range of -0.8-0.2 $\mathrm{V}$ in acidic in threeelectrode systems, which were summarized in Table 1 and Table S2. In all three-electrode testing 
systems, a platinum grid or stainless steel grid was used as counter electrode, a $\mathrm{Hg} / \mathrm{Hg}_{2} \mathrm{SO}_{4}$ (in acidic and neutral medium) or $\mathrm{Hg} / \mathrm{HgO}$ (in alkaline medium) as the reference electrode at room temperature.

$\mathrm{CV}$ was used to determine the effect of pore size distribution and functional groups on capacitances of carbon materials. The tests on three-electrode systems were conducted within a potential range of -0.8-0.2 $\mathrm{V}$ in acidic and neutral, and $-1.0-0 \mathrm{~V}$ or $-0.8-0.2 \mathrm{~V}$ in basic solutions. Figure $S_{7 a-f}$ shows the typical voltammograms of the capacitors fabricated with different samples at a scan rate of $10 \mathrm{mV} \mathrm{s}^{-1}$, demonstrating that the electrodes are stable within the potential range employed. In neutral solutions, the CVs of PANI-Zn-70o and pANI-Zn-8oo electrodes had a nearly regular rectangular-like shape, which was the characteristic behavior of an ideal capacitor, see Figure $S_{7}$. After surface oxidation, in addition to maintaining the rectangular-like shape, the CVs showed a pair of symmetrical, wide redox peaks in acid medium, which was considered as a result of the faradic pseudo-capacitance.

PANI-Zn-70o-40 presents capacitance in different solutions increasing in this order: $1 \mathrm{~mol} \mathrm{~L}^{-1}$ $\mathrm{Na}_{2} \mathrm{SO}_{4}<6 \mathrm{~mol} \mathrm{~L}^{-1} \mathrm{KOH}<1 \mathrm{~mol} \mathrm{~L}^{-1} \mathrm{H}_{2} \mathrm{SO}_{4}$ (Figure $\mathrm{S}_{7} \mathrm{~b}$ ). From Figure $\mathrm{S}_{7 \mathrm{c}}$, the capacitance increases as following: PANI-Zn-8oo $<$ PANI-Zn-70o $<$ PANI-Zn-6oo $<$ PANI-Zn-50o in $1 \mathrm{~mol} \mathrm{~L}^{-1} \mathrm{H}_{2} \mathrm{SO}_{4}$ solution, PANI-Zn-8oo $<$ PANI-Zn-70o $<$ PANI-Zn-8oo-4o $<$ PANI-Zn-70o-40 in 6 mol L-1 KOH solution (see Figure $\mathrm{S}_{7}$ ). In 1 mol L ${ }^{-1} \mathrm{H}_{2} \mathrm{SO}_{4}$ solution, PANI-Zn-50o-40 $<$ PANI-Zn-80o-40 $<$ PANIZn-70o-40 < PANI-Zn-6oo-40 (Figure S7d), and PANI-Zn-70o-25 $<$ PANI-Zn-70o-40 $<$ PANI-Zn70o-6o < PANI-Zn-70o-50 (Figure S7e). Figure S7g and S7h shows that both anodic and cathodic peak current density (the sum of adsorption and Faraday current density), $i_{p a}$ and $i_{p c}$, respectively, are increasing with the potential sweep rate in the CV measurements. Furthermore, $i_{p a}$ or $i_{p c}$ exhibits a linear relationship with the scan rate, and $\left|i_{p a} / i_{p c}\right| \approx 0.9$, does not change with the scan rate, see Figure $2 \mathrm{~h}$, indicating fast, quasi reversible interface Faraday processes induce the formation of the anodic and cathodic peaks.

Galvanostatic charge/discharge tests were used to investigate the supercapacitor performances of these samples, as shown in Figure S8. A three-electrod cell was assembled and charge/discharge measurements were carried out at a current density of $0.5-30 \mathrm{~A} \mathrm{~g}^{-1}$, Figure S8a. The charge- 
discharge curves show almost isosceles triangular shapes, suggesting excellent coulombic efficiency and ideal capacitor behavior. Figure S8b shows the variations in the specific capacitance (calculated from Eq. S1)of the materials with different current densities from $0.5-30 \mathrm{~A} \mathrm{~g}^{-1}$. It can be observed that the specific capacitance of PANI-Zn-6oo-40 is highest among all samples at low current density. Its specific capacitance drops from $360 \mathrm{~F} \mathrm{~g}^{-1}$ at $0.5 \mathrm{~A} \mathrm{~g}^{-1}, 211 \mathrm{~F} \mathrm{~g}^{-1}$ at $10 \mathrm{~A} \mathrm{~g}^{-1}$, to $142 \mathrm{~F}$ $\mathrm{g}^{-1}$ at $30 \mathrm{~A} \mathrm{~g}^{-1}$.

Furthermore, the surface area normalized capacitance $\left(C_{s}\right)$ has been calculated by dividing the gravimetric capacitance by the BET specific surface area, and the values were summarized in Table S2. At $0.5 \mathrm{~A} \mathrm{~g} \mathrm{~g}^{-1}$, the surface area normalized capacitance for PANI-Zn-70o-40 is $35.9 \mu \mathrm{F} \mathrm{cm}^{-2}$, which suggests another mechanism, a pseudofaradaic charge transfer, takes place. The $C_{s}$ of PANIZn-70o, 36.9 $\mu \mathrm{F} \mathrm{cm}^{-2}$ (Table S2), is equal to that of PANI-Zn-70o-40, meaning that the positive effect of oxidation (improving oxygen function content and enhancing the capacitor performance) and the negative effect of oxidation (causing unfavourable micropore distribution, see Table 3 , and degrading the performance) counteract each other. PANI-Zn-7oo-6o has the largest oxygen content, and thus has the greatest area capacitance among all samples. However, its area capacitance decreases with increasing discharge rate due to its large interface resistance.

Figure S8c and S8d shows the Ragone plots of average specific energy versus average specific power for symmetric two-electrode supercapacitors in $1 \mathrm{~mol} \mathrm{~L}^{-1} \mathrm{H}_{2} \mathrm{SO}_{4}$ solution. According to Eqs. $\mathrm{S}_{2}-\mathrm{S}_{4}$, the energy and power densities were calculated by means of constant-current charge/discharge of a supercapacitor using a cell-voltage window of $1 \mathrm{~V}$ and current densities between 0.5 and $30 \mathrm{~A} \mathrm{~g}^{-1}$. As a result of the existence of resistance potential drop, the usable voltage is often less than 1 volt, illustrated in Figure S8e and S8f. As shown in Figure S8c and S8d, PANI-Zn-70o-40 based capacitor exhibits excellent properties in both energy and power capacitance among all oxidation samples, however, its capacitor performance is exceeded by PANI-Zn-80o and PANI-Zn-70o at high discharge rate (only < 10.8 s), shown in Figure S8d. At a long current drain time of $280 \mathrm{~s}$, the values of the energy and power densities of PANI-Zn-70o-40 based capacitor are $9.47 \mathrm{Wh} \mathrm{kg}^{-1}$ and $123 \mathrm{~W} \mathrm{~kg}^{-1}$, respectively, and at a time of $3.6 \mathrm{~s}, \mathrm{E}=3.58 \mathrm{Wh}$ $\mathrm{kg}^{-1}, \mathrm{P}=3597 \mathrm{~W} \mathrm{~kg}$. PANI-Zn-70o shows $\mathrm{E}=8.42 \mathrm{Wh} \mathrm{kg}^{-1}, \mathrm{P}=122 \mathrm{~W} \mathrm{~kg}^{-1}$ at a long current drain 
time of $252 \mathrm{~s}$, respectively, and at a time of $3.6 \mathrm{~s}, \mathrm{E}=4.51 \mathrm{Wh} \mathrm{kg}^{-1}, \mathrm{P}=4595 \mathrm{~W} \mathrm{~kg}^{-1}$. At low discharge rate (108 $\mathrm{s}<\mathrm{t}<36 \mathrm{~s}$ ), the energy and power densities increase as following: PANI-Zn70o-6o $<$ PANI-Zn-70o-50 $<$ PANI-Zn-80o-40 $<$ PANI-Zn-70o-25 $<$ PANI-Zn-6oo-40 $<$ PANI-Zn70o-40; at moderate discharge rate (36 s $<\mathrm{t}<108 \mathrm{~s})$, PANI-Zn-70o-50 $<$ PANI-Zn-70o-6o $<$ PANIZn-80o-40 $<$ PANI-Zn-60o-40 $<$ PANI-Zn-70o-25 $<$ PANI-Zn-70o-40, at high discharge rate (10.8 $\mathrm{s}<\mathrm{t}<36 \mathrm{~s})$, PANI-Zn-70o-6o $<$ PANI-Zn-70o-5o $<$ PANI-Zn-6oo-4o $<$ PANI-Zn-8oo-40 $<$ PANIZn-70o-25 $<$ PANI-Zn-70o-40, and at very high discharge rate $(<3.6$ s), PANI-Zn-70o-50 $<$ PANIZn-70o-6o $<$ PANI-Zn-6oo-40 $<$ PANI-Zn-70o-25 $<$ PANI-Zn-80o-40 $<$ PANI-Zn-70o-40, see Furge S8c. As shown in Furge S8d, at low discharge rate $(108 \mathrm{~s}<\mathrm{t}<360 \mathrm{~s})$, PANI-Zn-6oo $<$ PANIZn-80o $<$ PANI-Zn-50o $<$ PANI-Zn-70o $<$ PANI-Zn-70o-40, at moderate discharge rate $(10.8 \mathrm{~s}<\mathrm{t}<$ 108 s), PANI-Zn-6oo < PANI-Zn-50o < PANI-Zn-8oo $<$ PANI-Zn-70o $<$ PANI-Zn-70o-40, and at high discharge rate (10.8 s $<\mathrm{t}<36 \mathrm{~s})$, PANI-Zn-50o $<$ PANI-Zn-6oo $<$ PANI-Zn-70o-40 $<$ PANI-Zn$800<$ PANI-Zn-70o. At low discharge current density, PEA-Zn-70o-6o and PANI-Zn-70o-50 capacitors show higher energy densities and power densities due to their rich functional groups (Figure S8C and Table S1). 

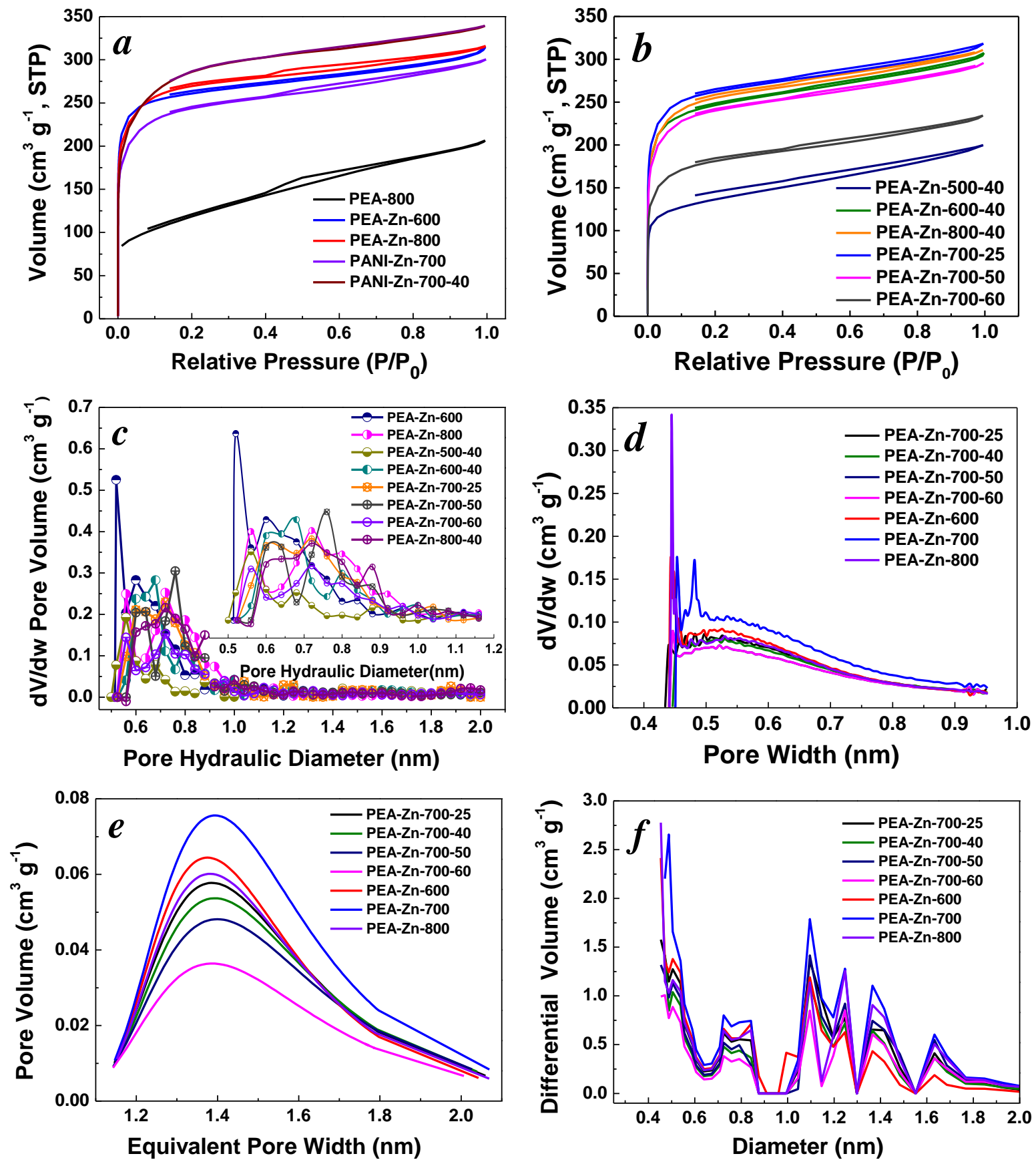

Figure S1. (a) and (b) Argon (87K) adsorption-desorption isotherms; (c), (d), (e) and (f) MP, HK, DA and NLDFT pore size distribution, respectively. 

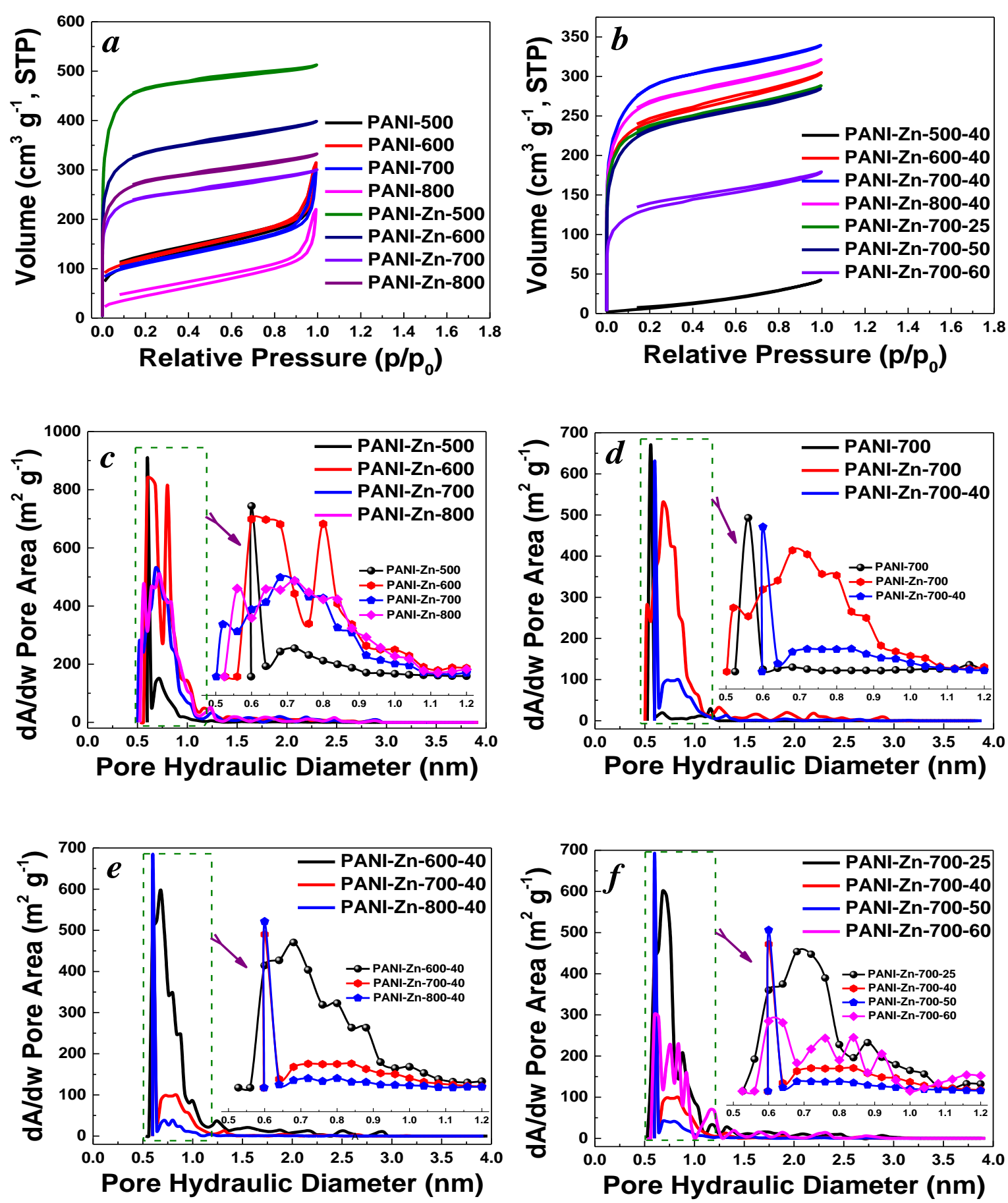

Figure S2. (a) and (b) Argon (87K) adsorption-desorption isotherms; (c), (d), (e) and (f) MP pore size distribution. 

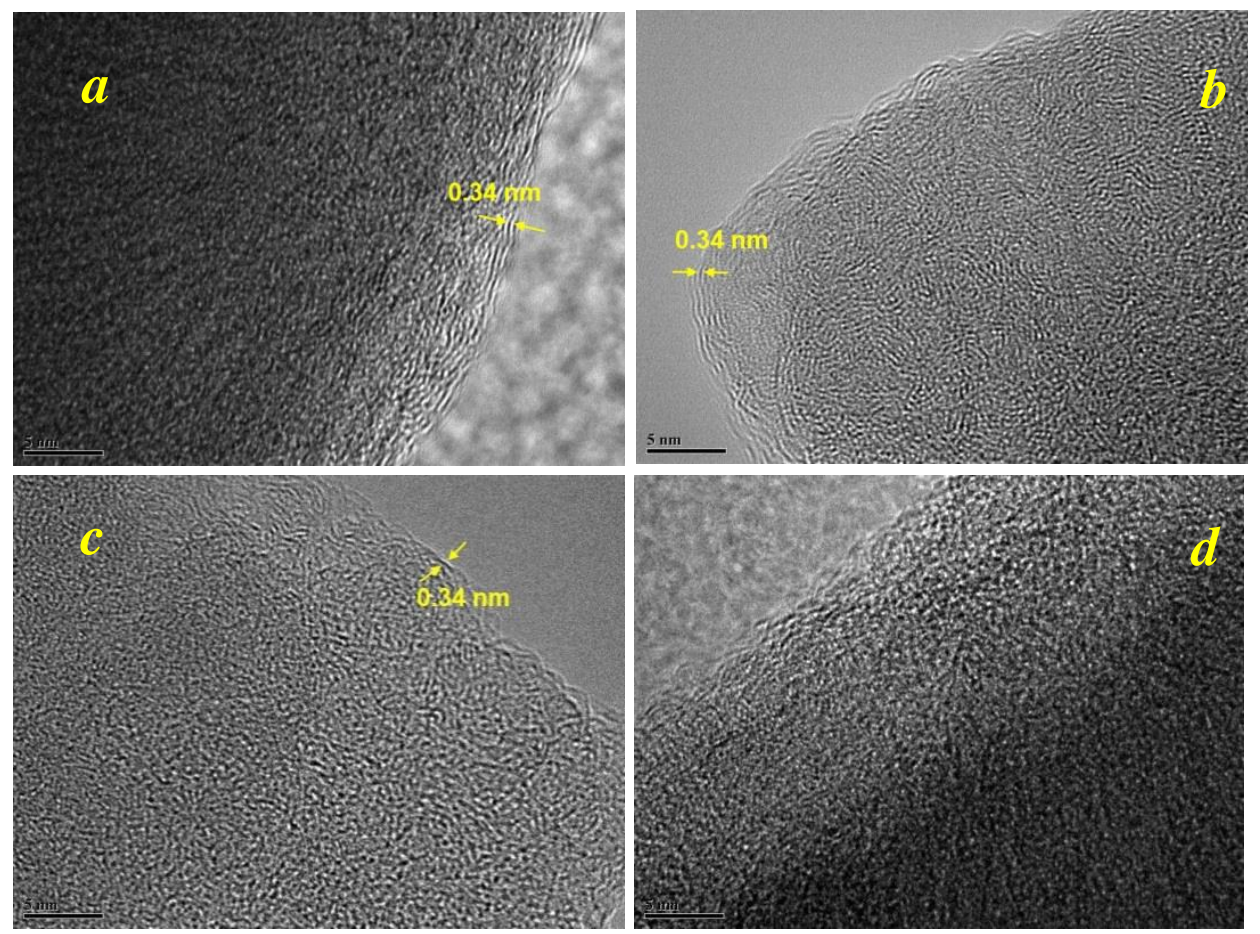

Figure S3. (a), (b), (c) and (d) TEM and HRTEM of PEA-70o, PEA-Zn-70o, PEA-Zn-70o-6o and PEA-Zn$800-40$, respectively. 


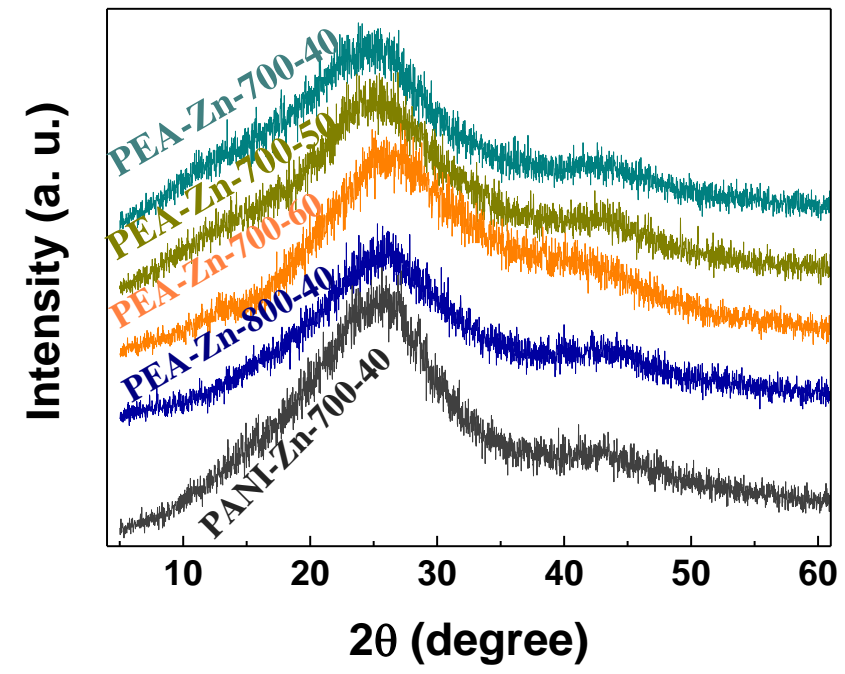

Figure S4. XRD patterns of PEA-Zn-70o-40, PEA-Zn-70o-5o, PEA-Zn-70o-6o, PEA-Zn-80o-40 and PANIZn-70o-40. 

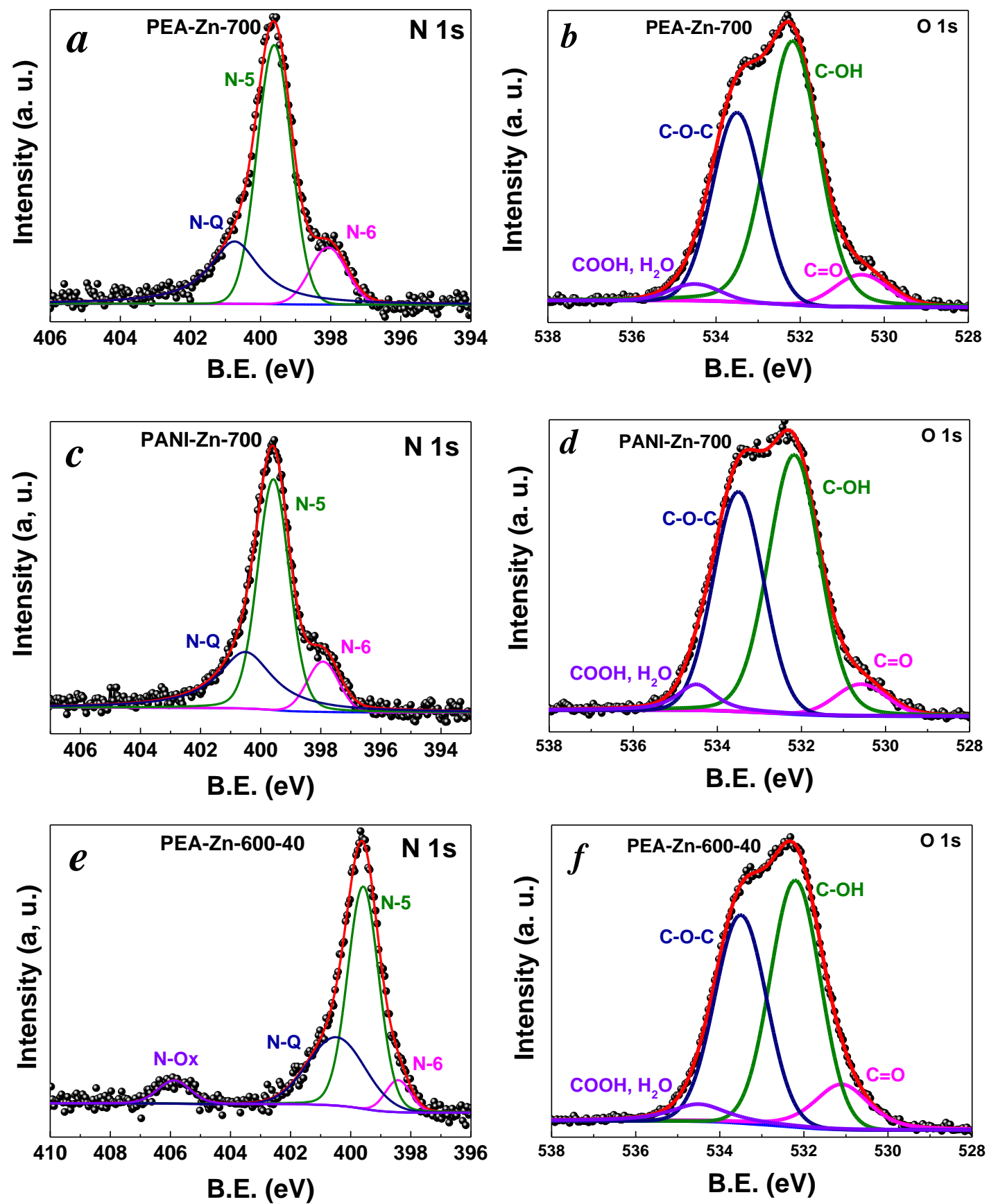

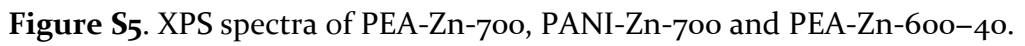



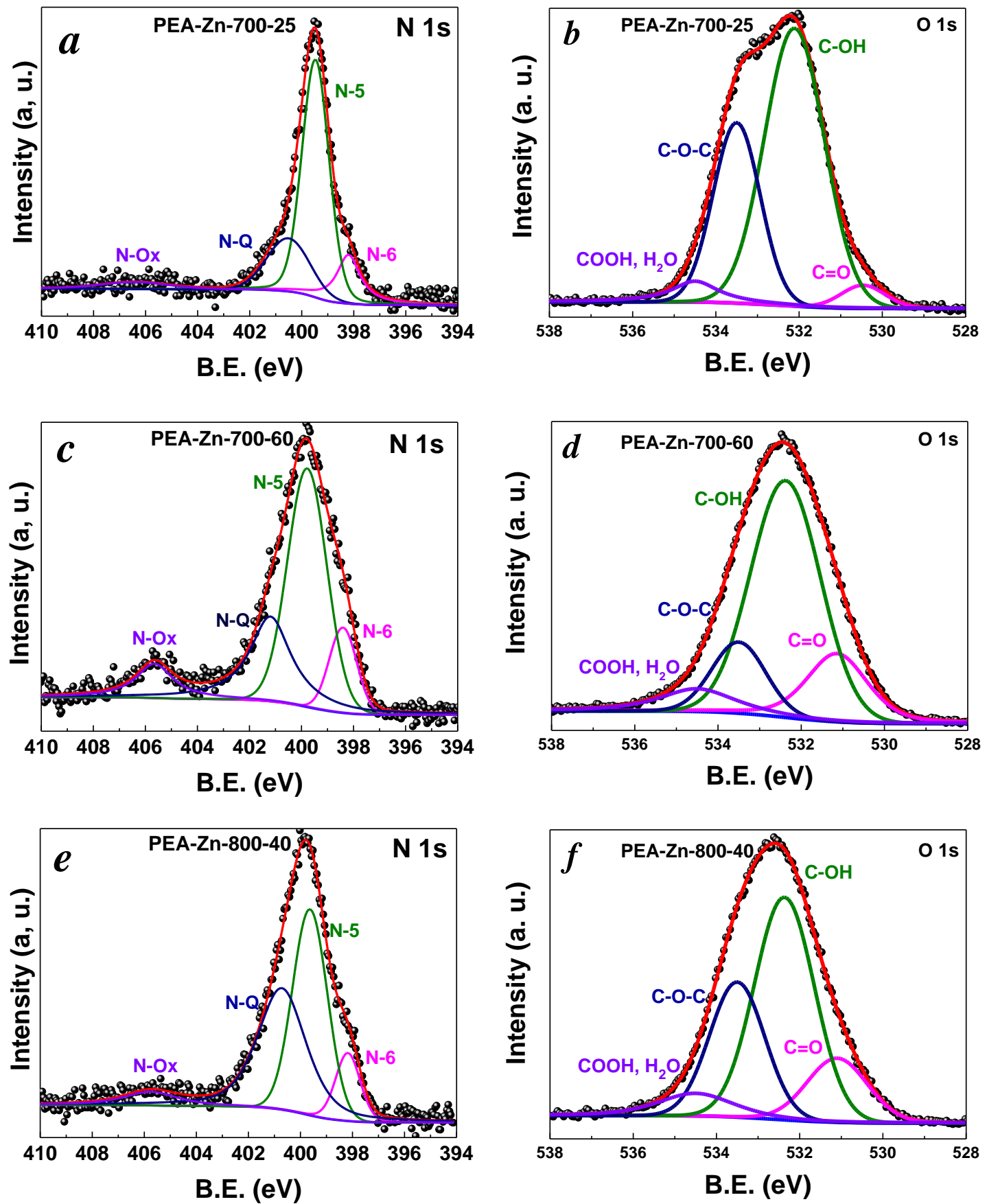

Figure S6. XPS spectra of PEA-Zn-70o-25, PEA-Zn-70o-6o and PEA-Zn-80o-40. 

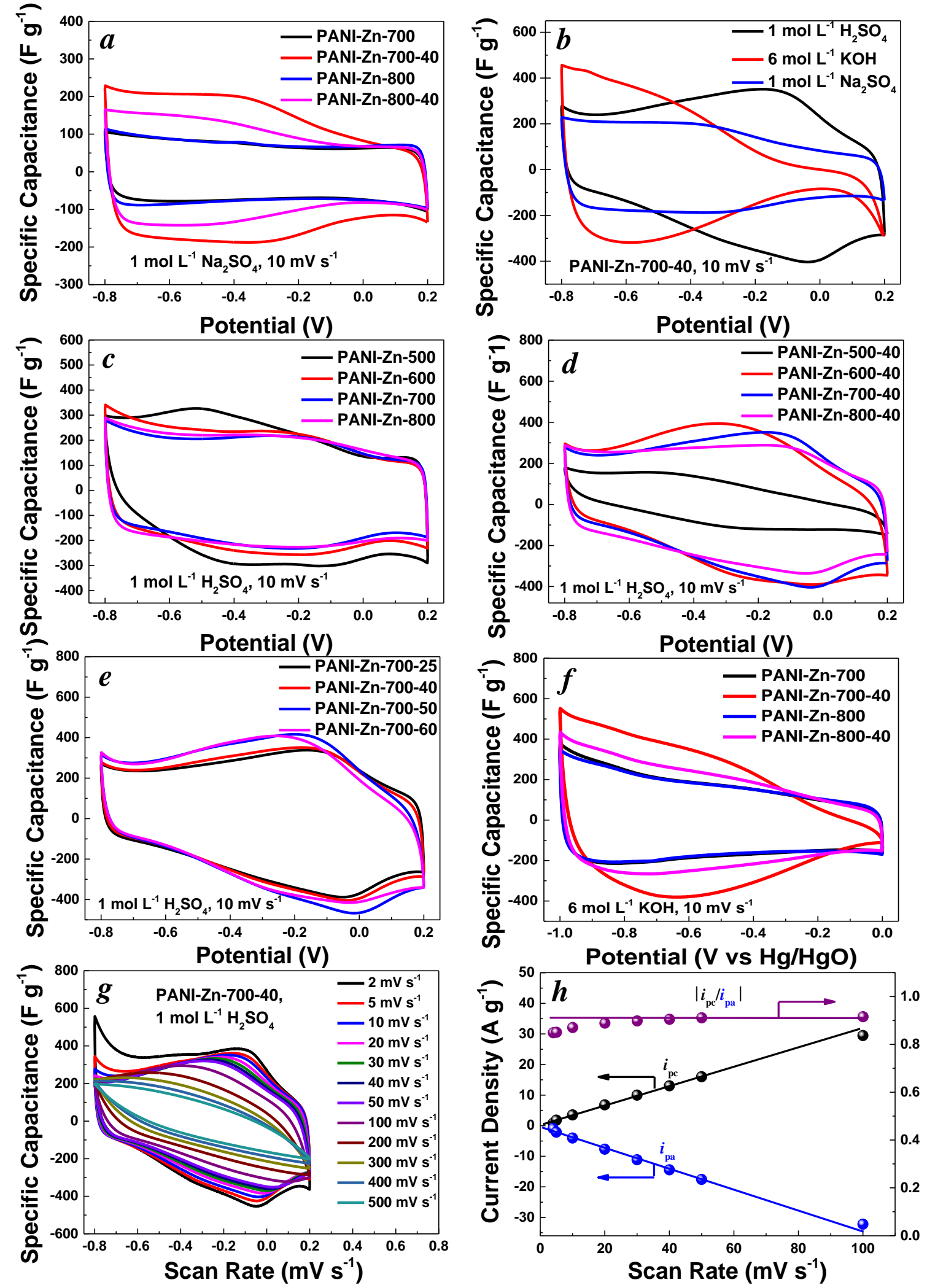

Figure S $_{7}$ CV behaviors of PANI-derived carbons for three-electrode system in different electrolyte aqueous solutions. Cyclic voltammetry at a scan rate of $10 \mathrm{mV} \mathrm{s}^{-1}$ (a) in $1 \mathrm{~mol} \mathrm{~L}^{-1} \mathrm{Na}_{2} \mathrm{SO}_{4}$; (b) PANI-Zn- 
$700-40$ in $1 \mathrm{~mol} \mathrm{~L}^{-1} \mathrm{Na}_{2} \mathrm{SO}_{4}, 6 \mathrm{~mol} \mathrm{~L}^{-1} \mathrm{KOH}$ and $1 \mathrm{~mol} \mathrm{~L}^{-1} \mathrm{H}_{2} \mathrm{SO}_{4}$; (c), (d) and (e) in $1 \mathrm{~mol} \mathrm{~L}^{-1} \mathrm{H}_{2} \mathrm{SO}_{4}$; (f) in 6 mol L ${ }^{-1} \mathrm{KOH}$. (g) Cyclic voltammetry of PANI-Zn-70o-40 at different scan rates in $1 \mathrm{~mol} \mathrm{~L}^{-1} \mathrm{H}_{2} \mathrm{SO}_{4}$, and (h) the relationship between the peak current densities and the scan rates corresponding to $(\mathrm{g})$. 

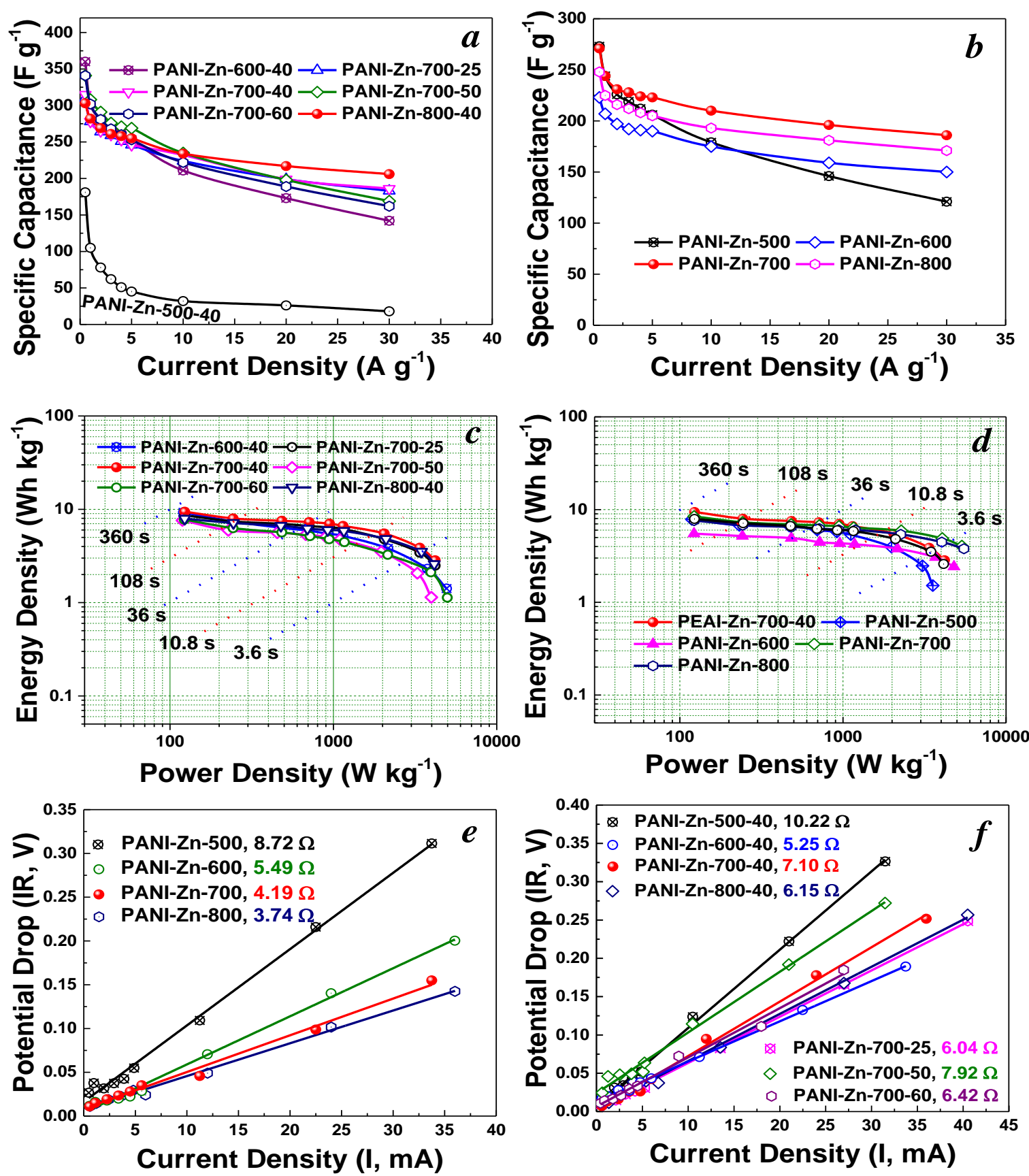

Figure S8 Galvanostatic charge/discharge of cells assembled by three electrodes in $1 \mathrm{~mol} \mathrm{~L}^{-1} \mathrm{H}_{2} \mathrm{SO}_{4}$ solutions: (a), (b) the specific capacitances at various discharge current densities. (c), (d) Ragone plots about the relationship between the energy density and power density of samples in two symmetrical electrode cells using $1 \mathrm{~mol} \mathrm{~L}^{-1} \mathrm{H}_{2} \mathrm{SO}_{4}$ as electrolyte solutions; (e), (f) the linear relationship between potential drop (IR) and current (I) about two-electrode cells. 


\section{FT-IR spectra}

The FT-IR spectrum of sulfuric acid doped PNPEA polymer is shown in Figure $\mathrm{h}$. A broad band at about $3420 \mathrm{~cm}^{-1}$ is due to $\mathrm{N}-\mathrm{H}$ and $\mathrm{O}-\mathrm{H}$ stretching overlapping peak. ${ }^{[\mathrm{S} 9]}$ A peak shoulder at $3556 \mathrm{~cm}^{-1}$ is attributed to free $\mathrm{O}-\mathrm{H}$ stretching vibration, and another at $3240 \mathrm{~cm}^{-1}$ may be due to associated $\mathrm{O}-\mathrm{H}$ stretching vibration. The peaks observed at about 1,637 and 1,618 $\mathrm{cm}^{-1}$ for both the polymer and the carbon samples, respectively, are attributed to the bending vibration of the $\mathrm{N}-\mathrm{H}$ bond and $\mathrm{C}=\mathrm{C}$ stretching vibration or stretching band of carbonyl group. ${ }^{\left[{ }_{9}-\mathrm{S}_{2}\right]}$ The bands at approximately 1618 and $1558 \mathrm{~cm}^{-1}$ are due to the quinoid ring units, and the band at about $1507 \mathrm{~cm}^{-1}$ suggests the presence of benzenoid rings. ${ }^{\left[\mathrm{S}_{13}\right]}$ The $\mathrm{C}-\mathrm{N}$ stretching vibrations is observed at about $1384 \mathrm{~cm}^{-1}$. ${ }^{\left[\mathrm{S}_{4}\right]}$ The broad band spanning $1253-1178 \mathrm{~cm}^{-1}$ is assigned to $\mathrm{O}-\mathrm{H}$ bending modes. The bands at $616,1002,1072$, and $1121 \mathrm{~cm}^{-1}$ are due to sulfonate stretching. When PNPEA polymer was carbonized at $700{ }^{\circ} \mathrm{C}$, the band intensity at $1178 \mathrm{~cm}^{-1}$, O-H bending mode, weakened, and a new band at $1253 \mathrm{~cm}^{-1}$ appeared, which is due to C-O$C$ vibrations in ether structures. ${ }^{\left[\mathrm{S}_{5}\right]}$ Two peak shoulders at 3556 and $3240 \mathrm{~cm}^{-1}$ disappeared, which means that hydroxyl content of the sample had been reduced. The peak intensity dropped at about $1636 \mathrm{~cm}^{-1}$ as the nitrogen content of samples decreasing at high temperature. Activation and oxidation could increase the content of carboxyl and hydroxyl of samples, and peaks or peak shoulders emerged at 3420 and $3556 \mathrm{~cm}^{-1}$, respectively, and their strength gradually increased with oxidation temperature increasing. Moreover, oxidation would produce carbonyl and quinone functional groups on carbon samples, which is beneficial to enhance the peak intensity at about $1636 \mathrm{~cm}^{-1}$. Astonishingly, PEA-Zn$700-40$ possesses highest peak intensity at about $1636 \mathrm{~cm}^{-1}$ among all samples (shown in the curve $\mathrm{d}$ in Figure $1 \mathrm{~h}$ ), meaning that oxidation gives PEA-Zn-70o-40 a maximum content of carbonyl and quinone functional groups useful to enhance pseudo-capacitance. This result is approximately consistent with that of XPS data results (Table S1). 


\section{Tentative Pyrolysis mechanism}

The carbonization of nitrogen-containing polymers such as PANI and its derivatives presents a relatively effective way to obtain $\mathrm{N}$-containing carbons with tailored morphology and high nitrogen content (up to $10 \%$ ). ${ }^{[\mathrm{S} 16]}$ It is necessary to explore the structural changes of PANI and its derivatives during the pyrolysis process to understand the relationship between their structures and performance. The changes in the molecular structure during the carbonization are conveniently observed by Raman spectroscopy, IR spectrum, X-ray photoelectron spectroscopy, X-ray diffraction, scanning and transmission electron microscopy, thermogravimetric analysis or conductivity measurements. ${ }^{\left[{ }_{16}-\mathrm{S}_{24}\right]}$ The thermal stability of PANI and N-alkyl substituted PANI have been investigated by numerous authors $^{\left[{ }^{[16-S} \mathrm{S}_{9}\right]}$ and the results have shown that undoped PANI has a very good thermal stability, which significantly decreases after doping with protonic acids. And N-alkyl substitution and phenyl ring substitution can also lower the thermal stability of PANI. ${ }^{\left[{ }_{19}\right]}$ As for the mechanism of PANI pyrolysis, it is widely believed that doped PANI undergoes a series of extrinsic or intrinsic changes during heat treatment such as doping, dedoping, conversion of some benzenoid rings to quinoid rings through chain scission and crosslink formation. ${ }^{\left[\mathrm{S}_{18}, \mathrm{~S}_{20}-\mathrm{S}_{24}\right]}$ The probable pyrolysis mechanism is drafted in Schemes S1 and S2. Doped PANI is composed of chained aniline molecules, and one half of the nitrogen being of the quaternary type and the other of the secondary amine type (Scheme S1, formula 1). Crosslinking is probably the most important reaction which modifies the molecular structure of PANI at elevated temperature. The dedoped molecule structure (2) and phenazine heterocycles (3) form when the PANI is exposed to $200-300{ }^{\circ} \mathrm{C}$ through dedoping, protonated dehydrogenation and crosslinking processes. ${ }^{\left[\mathrm{S}_{18}, \mathrm{~S}_{20}, \mathrm{~S}_{23}, \mathrm{~S}_{24}\right]}$ The proposed cross-linking (3) does not lead to a change of the C/N ratio, whose decrease, however, is observed at pyrolysis temperature of $300-600{ }^{\circ} \mathrm{C}$, suggesting opening benzenoid or quinonoid rings, releasing ammonia gas, and resultantly forming (4) as described in Scheme S1. The N/C ratio further decreases in the pyrolysis range of $600-800{ }^{\circ} \mathrm{C}$ due to the carbonization and crosslinking of (4) to release the ammonia gas and form (5) via chain scission. To the best of our knowledge, there is no literature about PAPEA pyrolysis, so the speculated pyrolysis mechanism is tentatively shown in Scheme S2. PNPEA has the similar pyrolysis mechanism with that of PANI. However, the difference between them is that quinone structure (7) is more easily formed in 
the doped PNPEA (6) than in PANI due to that the N-C bond energy (in - $-\mathrm{CH}_{2} \mathrm{CH}_{2} \mathrm{OH}$ molecule, about $\left.307 \mathrm{~kJ} \mathrm{~mol}^{-1}\right)^{\left[{ }_{225]}\right.}$ is lower than that of N-H (in PANI molecule, $385.8 \mathrm{~kJ} \mathrm{~mol}^{-1}$ ). ${ }^{\left[\mathrm{S}_{2} 6\right]}$ Moreover, the chemical activity of (7) is higher than that of (2), and therefore (8) is formed in lower temperature, which may result in that PNPEA-derived carbons are easily graphitized than PANI-based carbons as shown in Figure 1d. Chemical activator, such as $\mathrm{ZnCl}_{2}$, can accelerate the decomposition of PANI and its derivatives, and even perhaps change their pyrolysis mechanism different from the one described in Schemes $\mathrm{S}_{1}$ and S2. And aslo, there is no literature about the pyrolysis of PANI and its derivatives in the presence of chemical activators. $\mathrm{ZnCl}_{2}$ is a kind of weak acid and a dehydrator, which can be hydrolyzed to produce $\mathrm{H}^{+}$during PNPEA pyrolysis, so the protonated ethoxy units (10) would be formed from ethoxy units (9), and then, (10) probably generates the phenoxazine units (11) and pyrroline units (12) through a deprotonation process and a dehydration process, respectively. Perhaps (12) produces pyrrole units (13) at high temperature. Moreover, in addition to increasing the surface area and changing the pore size distribution of carbon, $\mathrm{ZnCl}_{2}$ activation also leads to an increase in the concentration of surface oxygen functional groups, as proved in recent literature. ${ }^{\left[\mathrm{S}_{3}\right]}$ Surface functional groups, nitrogen, especially oxygen groups (i.e. hydroxy, quinone and phenol) increase specific capacitance of carbon materials by forming reversible redox pseudo-faradaic capacitor. Nitrogen and oxygen containing carbons can be synthesized from suitable nitrogen or oxygencontaining precursors. Oxidation is one of the most effective methods to produce surface oxygen functional groups. ${ }^{\left[{ }_{2} 7\right]}$ It involves the use of nitric acid, sulfuric acid, phosphoric acid, alone or in combination with hydrogen peroxide, sodium hypochlorite, permanganate, chromate or dichromate of potassium, transition metal nitrates, etc.. ${ }^{\left[{ }_{15}, S_{22}, S_{28}\right]}$ Our results show that oxidation not only changes the surface oxygen functional groups, but also changes the pore size distribution of carbons. 


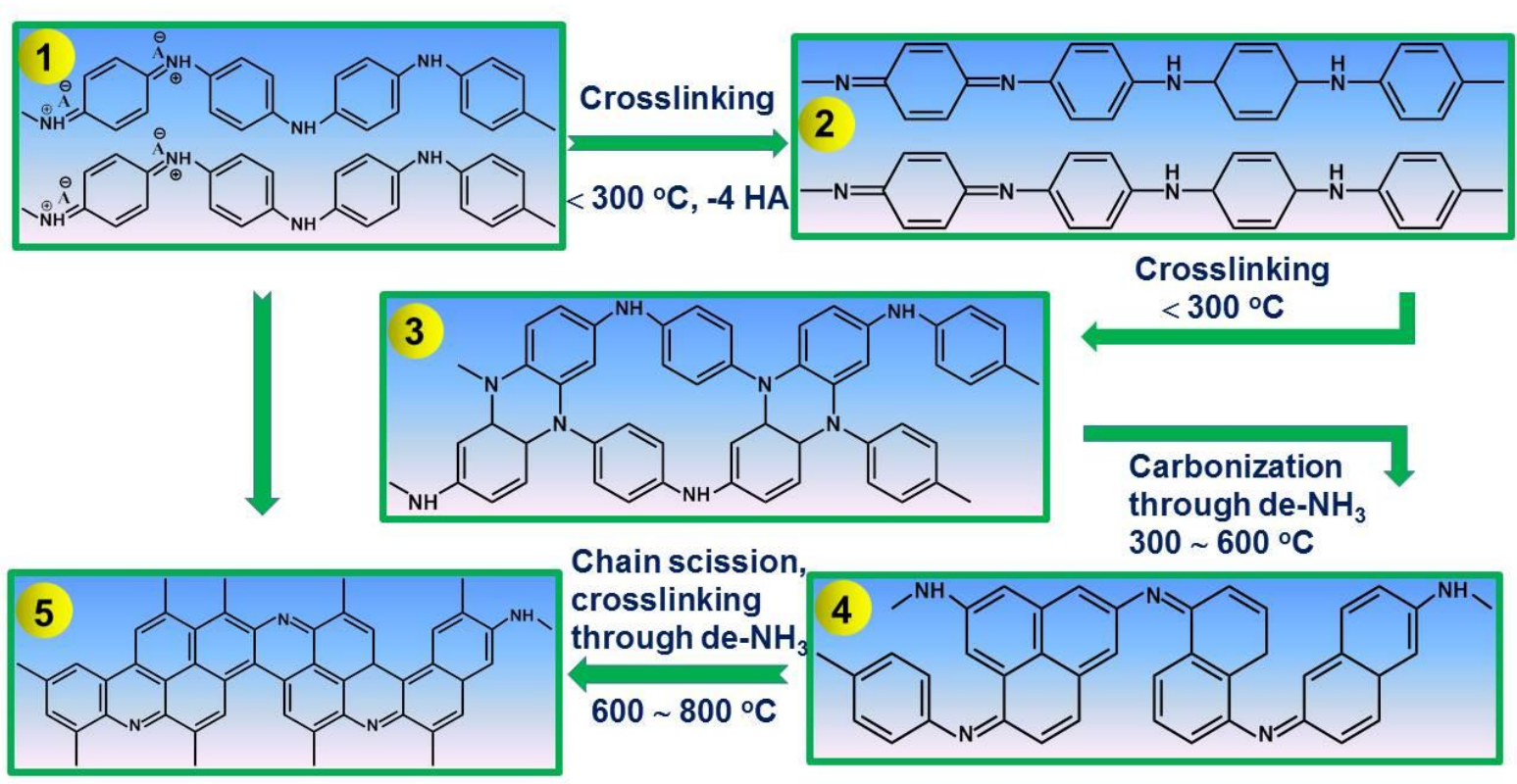

Scheme S1. The possible mechanism of PANI in inert atmosphere.
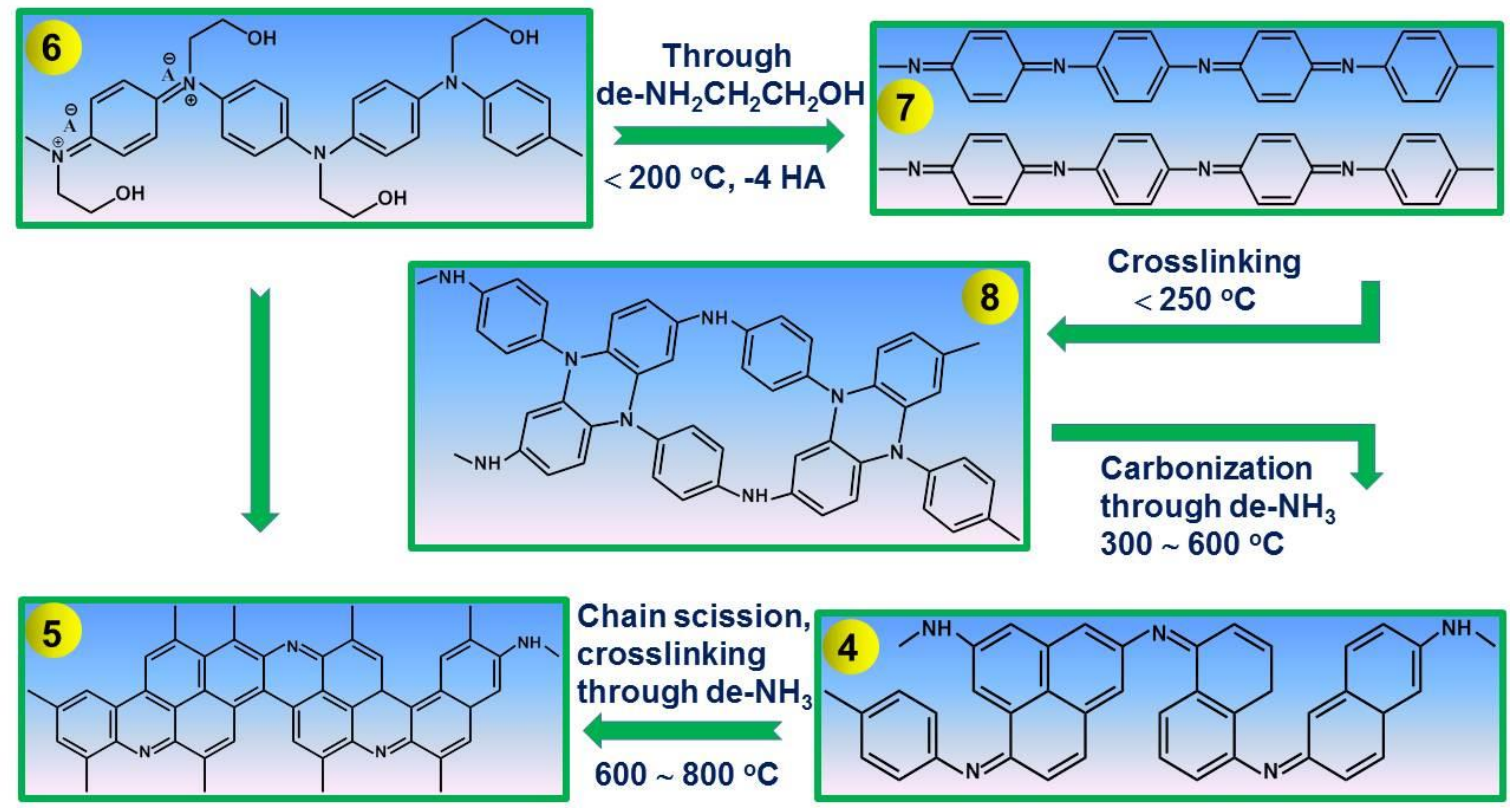

Scheme S2. The possible mechanism of PNPEA in inert atmosphere. 


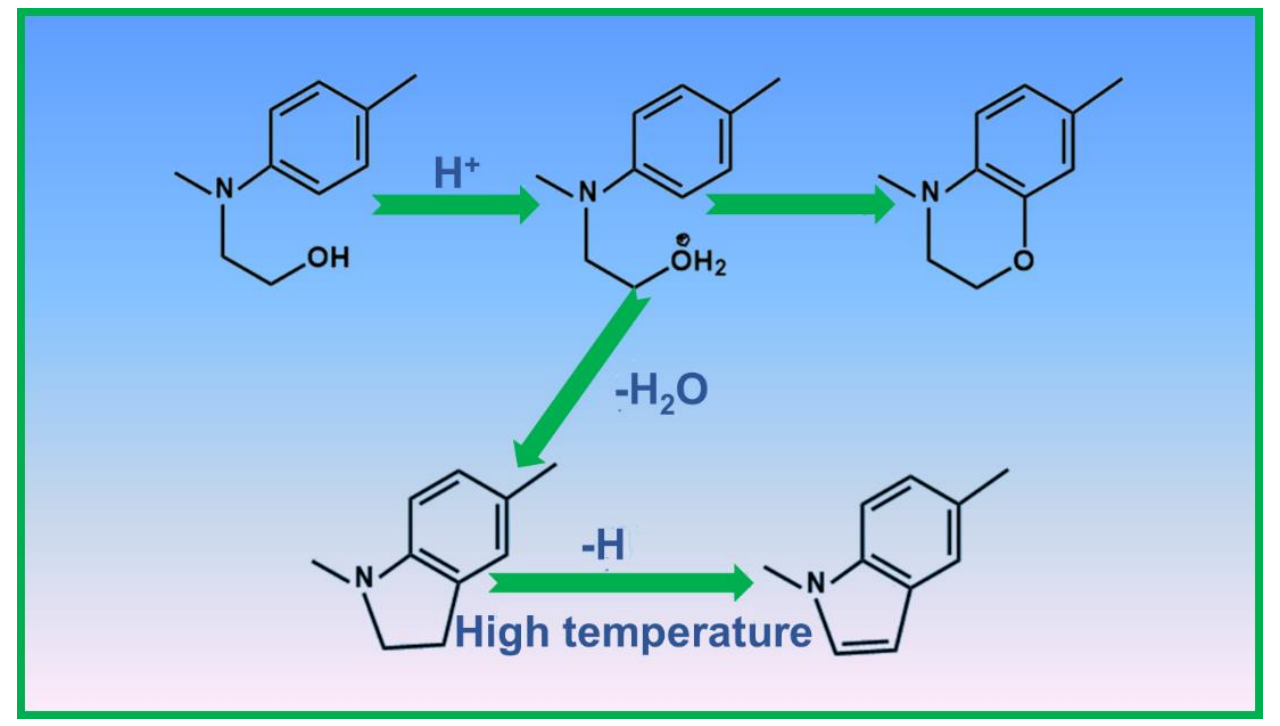

Scheme $\mathrm{S}_{3}$. The possible mechanism of PNPEA with as $\mathrm{ZnCl}_{2}$ chemical activator. 
Table Si Surface Atomic Percentage of Nitrogen, Oxygen, Nitrogen- and Oxygen-Containing Functional Groups Determined By XPS Analysis.

\begin{tabular}{|c|c|c|c|c|c|c|c|c|c|c|}
\hline \multirow{2}{*}{ Sample } & \multicolumn{2}{|c|}{ XPS (\%) } & \multirow{2}{*}{$\mathrm{N}-6$} & \multirow{2}{*}{$\mathrm{N}-5$} & \multirow{2}{*}{$\mathrm{N}-\mathrm{Q}$} & \multirow{2}{*}{$\mathrm{N}-\mathrm{Ox}$} & \multirow{2}{*}{$\mathrm{C}=\mathrm{O}$} & \multirow{2}{*}{$\mathrm{C}-\mathrm{OH}$} & \multirow{2}{*}{$\mathrm{C}-\mathrm{O}-\mathrm{C}$} & \multirow{2}{*}{$\begin{array}{l}\mathrm{COOH}, \\
\text { or } \mathrm{H}_{2} \mathrm{O}\end{array}$} \\
\hline & $\mathrm{N}$ is & $\mathrm{O}$ is & & & & & & & & \\
\hline PEA-Zn-6oo-40 & 2.96 & 15.83 & 6.4 & 56.57 & 30.64 & 6.4 & 10.7 & 45.2 & $39 \cdot 3$ & 4.8 \\
\hline PEA-Zn-70o & 2.93 & 12.79 & 13.31 & 56.66 & 30.03 & - & 12.8 & 48.7 & 35 & 3.5 \\
\hline PEA-Zn-70o-25 & 2.85 & $15 \cdot 3$ & 14.98 & $59 \cdot 58$ & 20.56 & 4.88 & 10.6 & 53.1 & 30.9 & $5 \cdot 4$ \\
\hline PEA-Zn-70o-40 & 3.02 & 16.65 & 8.94 & $54 \cdot 97$ & 28.15 & $7 \cdot 95$ & 16.1 & $54 \cdot 7$ & 25.1 & 4.1 \\
\hline PEA-Zn-70o-6o & $3 \cdot 98$ & $25 \cdot 75$ & 12.34 & 50.13 & 27.46 & 10.08 & 16.6 & 60.3 & 14.6 & 8.5 \\
\hline PEA-Zn-8oo-40 & 3.26 & 19.61 & 10.4 & 41.59 & 42.2 & 5.81 & $14 \cdot 7$ & 49.8 & $27 \cdot 7$ & 7.8 \\
\hline PANI-Zn-70o & 3.63 & 12.32 & 11.26 & $55 \cdot 49$ & 33.24 & - & 11.4 & $44 \cdot 7$ & 38.9 & 5.1 \\
\hline
\end{tabular}


Table S2. Surface Textural Properties and Electrochemical Capacitance Performance of the $\mathrm{PANI}^{\mathrm{Samples}}$ in $\mathrm{H}_{2} \mathrm{SO}_{4}$ Solutions.

\begin{tabular}{|c|c|c|c|c|c|c|c|c|c|c|}
\hline \multirow[b]{2}{*}{ Sample } & \multirow[b]{2}{*}{$\begin{array}{c}S_{\mathrm{BET}}^{a} \\
\left(\mathrm{~m}^{2} \mathrm{~g}^{-1}\right)\end{array}$} & \multirow{2}{*}{$\begin{array}{c}V_{\mathrm{t}}^{b} \\
\left(\mathrm{~cm}^{3} \mathrm{~g}^{-1}\right)\end{array}$} & \multicolumn{6}{|c|}{ Pore volume distribution (Percentage, \%) } & \multirow[b]{2}{*}{$\begin{array}{c}C_{\mathrm{g}}^{f} \\
\left(\mathrm{~F} \mathrm{~g}^{-1}\right)\end{array}$} & \multirow[b]{2}{*}{$\begin{array}{c}C_{s}^{g} \\
\left(\mu \mathrm{F} \mathrm{cm}^{-2}\right)\end{array}$} \\
\hline & & & $P_{<2 \mathrm{~nm}}{ }^{c}$ & $P_{2-5 \mathrm{~nm}}{ }^{d}$ & $P_{5 \text {-10nm }}{ }^{d}$ & $P_{10-50 n m}{ }^{d}$ & $P_{>5 \mathrm{onm}}{ }^{d}$ & $\begin{array}{c}D_{\text {meso }}{ }^{2} \\
(\mathrm{~nm})\end{array}$ & & \\
\hline PANI-6oo & 400.3 & 0.4868 & 21.67 & $23 \cdot 77$ & 10.20 & $13 \cdot 94$ & 30.43 & 7.06 & $55.1^{h}$ & $13 \cdot 7^{h}$ \\
\hline PANI-700 & 364.8 & 0.4586 & 20.74 & $23 \cdot 34$ & 9.69 & 15.84 & 30.38 & $7 \cdot 71$ & $103.2^{h}$ & $28.2^{h}$ \\
\hline PANI-8oo & 172.8 & 0.3405 & 4.67 & 23.20 & 11.99 & 18.25 & 41.90 & 8.29 & $63 \cdot 3^{h}$ & $36.4^{h}$ \\
\hline PANI-Zn-6oo-40 & 732.5 & 0.3849 & 50.43 & 22.31 & 11.37 & 11.72 & 4.16 & 4.62 & $360.2^{h}$ & 49.2 \\
\hline PANI-Zn-700-25 & 709.9 & 0.3653 & $53 \cdot 79$ & 20.53 & 10.62 & 10.74 & $4 \cdot 32$ & 4.63 & $309.6^{h}$ & $43.6^{h}$ \\
\hline PANI-Zn-70o-40 & 877 & 0.4307 & 42.72 & $27 \cdot 38$ & 12.63 & 12.7 & $4 \cdot 57$ & 4.81 & $315.2^{h}$ & $35 \cdot 9^{h}$ \\
\hline PANI-Zn-700-50 & 706.4 & 0.3602 & 44.78 & 26.60 & 10.85 & 13.00 & $4 \cdot 77$ & $4 \cdot 90$ & $341.3^{h}$ & $48.3^{h}$ \\
\hline PANI-Zn-70o-6o & $404 \cdot 7$ & 0.2249 & 38.64 & 27.27 & 13.69 & 14.94 & $5 \cdot 45$ & 4.68 & $339.6^{h}$ & $83.9^{h}$ \\
\hline PANI-Zn-80o-40 & 810.2 & 0.4065 & 48.63 & 23.00 & 11.27 & 11.65 & $5 \cdot 44$ & $4 \cdot 58$ & $303.2^{h}$ & $37 \cdot 4^{h}$ \\
\hline PANI-Zn-500 & 1395.6 & 0.6508 & 64.17 & $17 \cdot 79$ & 7.26 & 6.54 & 4.25 & 4.25 & $273.1^{h}$ & $19.6^{h}$ \\
\hline PANI-Zn-6oo & 1009.1 & 0.5053 & 54.44 & 20.87 & 10.26 & 10.22 & 4.21 & 4.49 & $223 \cdot 4^{h}$ & $22.1^{h}$ \\
\hline PANI-Zn-70o & $735 \cdot 3$ & 0.3798 & $54 \cdot 4$ & 18.86 & 11.67 & 11.37 & $3 \cdot 7$ & $5 \cdot 38$ & $271.3^{h}$ & $36.9^{h}$ \\
\hline PANI-Zn-8oo & 834.5 & 0.4205 & 51.72 & 20.91 & 10.68 & 11.40 & 5.29 & 4.69 & $247.9^{h}$ & $29.7^{h}$ \\
\hline
\end{tabular}

a) BET surface area; $\left.{ }^{b}\right)$ Single point adsorption total pore volume of pores at $\mathrm{p} / \mathrm{p}_{\mathrm{o}}=0.995$; ${ }^{\mathrm{c})}$ The micropore percentage calculated by micropore $(<2 \mathrm{~nm})$ volume divided by total pore volume $\left(\mathrm{V}_{\mathrm{t}}\right)$; ${ }^{\mathrm{d})}$ The mesopore or macropore percentage in different pore diameter range, such as $\mathrm{P}_{2-5 \mathrm{~nm}}=\left(100-\mathrm{P}_{<2 \mathrm{~nm}}\right) \mathrm{V}_{2-5 \mathrm{~nm}} / \mathrm{V}_{\mathrm{BJH}}, \mathrm{V}_{2-5 \mathrm{~nm}}$ : BJH adsorption cumulative volume of pores between $2 \mathrm{~nm}$ and $5 \mathrm{~nm}$ width, $\mathrm{V}_{\mathrm{BJH}}: \mathrm{BJH}$ adsorption cumulative volume of pores between $2 \mathrm{~nm}$ and $300 \mathrm{~nm}$ width; ${ }^{\mathrm{e}} \mathrm{BJH}$ adsorption average pore width $\left(4 \mathrm{~V}_{\mathrm{BJH}} / \mathrm{A}\right.$, A: BJH Adsorption cumulative surface area of pores between $2.0 \mathrm{~nm}$ and $300.0 \mathrm{~nm}$ width); ${ }^{\text {f) }}$ Specific capacitance and ${ }^{\text {g) }}$ Area-specific capacitance that normalized to the $\mathrm{S}_{\text {ВET. }}$. The value capacitance evaluated by three-electrode system at ${ }^{\mathrm{h})} 0.5 \mathrm{~A} \mathrm{~g}^{-1}$ current density. 
Table S3. Comparison of Electrochemical Performance of Carbon from Different Carbon Sources.

\begin{tabular}{|c|c|c|c|c|c|c|c|}
\hline Carbon source & Activating agent & $\begin{array}{c}\text { BET surface } \\
\text { area } \\
\left(\mathrm{m}^{2} \mathrm{~g}^{-1}\right)\end{array}$ & Electrolyte & $\begin{array}{c}\mathrm{C}_{\mathrm{g}}{ }^{a} \\
\left(\mathrm{~F} \mathrm{~g}^{-1}\right)\end{array}$ & $\begin{array}{c}\mathrm{C}_{\mathrm{s}}^{b} \\
\left(\mu \mathrm{F} \mathrm{cm}^{-2}\right)\end{array}$ & $\begin{array}{l}\text { Current } \\
\text { density } \\
\left(\mathrm{Ag}^{-1}\right)\end{array}$ & Reference \\
\hline Sugar-cane bagasse & $\mathrm{ZnCl}_{2}$ & 1788 & $1 \mathrm{~mol} \mathrm{~L}^{-1} \mathrm{H}_{2} \mathrm{SO}_{4}$ & $300^{d}$ & 16.8 & 0.250 & $S(3)$ \\
\hline Protein & Template & 805.7 & $1 \mathrm{~mol} \mathrm{~L}^{-1} \mathrm{H}_{2} \mathrm{SO}_{4}$ & $390^{c}$ & 48.4 & 0.250 & $S(29)$ \\
\hline Artemia cyst shell & $\mathrm{KOH}$ & 1384 & $1 \mathrm{~mol} \mathrm{~L}^{-1} \mathrm{H}_{2} \mathrm{SO}_{4}$ & $369^{c}$ & 26.7 & 0.500 & $S(30)$ \\
\hline Waste coffee bagasse & $\mathrm{ZnCl}_{2}$ & 1019 & $1 \mathrm{~mol} \mathrm{~L}^{-1} \mathrm{H}_{2} \mathrm{SO}_{4}$ & $368^{d}$ & 36.1 & 0.050 & $S(31)$ \\
\hline Argan seed shell & $\mathrm{KOH} /$ melamine & 2062 & $1 \mathrm{~mol} \mathrm{~L}^{-1} \mathrm{H}_{2} \mathrm{SO}_{4}$ & $355^{c}$ & 17.2 & 0.125 & $S(32)$ \\
\hline Neem dead leaves & No activation & 1230 & $1 \mathrm{~mol} \mathrm{~L}^{-1} \mathrm{H}_{2} \mathrm{SO}_{4}$ & $400^{d}$ & 32.5 & 0.500 & $S(33)$ \\
\hline Schiff-Base & $\mathrm{ZnCl}_{2}$ & 1203 & $1 \mathrm{~mol} \mathrm{~L}^{-1} \mathrm{H}_{2} \mathrm{SO}_{4}$ & $377^{c}$ & 31.3 & 0.200 & $S(34)$ \\
\hline Petroleum residue & $\mathrm{KOH}$ & 2652 & $1 \mathrm{~mol} \mathrm{~L}^{-1} \mathrm{H}_{2} \mathrm{SO}_{4}$ & $334^{d}$ & 12.6 & 0.050 & $S(35)$ \\
\hline Viscose fibers & $\mathrm{KOH}$ & 1374 & $4 \mathrm{~mol} \mathrm{~L}^{-1} \mathrm{H}_{2} \mathrm{SO}_{4}$ & $336^{c}$ & $24 \cdot 5$ & 0.200 & $S(36)$ \\
\hline MeadWestvaco & $\mathrm{HNO}_{3} /$ melamine & 1435 & $1 \mathrm{~mol} \mathrm{~L}^{-1} \mathrm{H}_{2} \mathrm{SO}_{4}$ & $316^{d}$ & 22.0 & 0.100 & $S(37)$ \\
\hline Acrylonitrile & Zeolite template & 1680 & $1 \mathrm{~mol} \mathrm{~L}^{-1} \mathrm{H}_{2} \mathrm{SO}_{4}$ & $340^{d}$ & 20.2 & 0.100 & $S(38)$ \\
\hline Camellia oleifera shell & $\mathrm{ZnCl}_{2}$ & 3935 & $1 \mathrm{~mol} \mathrm{~L}^{-1} \mathrm{H}_{2} \mathrm{SO}_{4}$ & $374^{c}$ & $9 \cdot 5$ & 0.200 & $S(39)$ \\
\hline PANI & $\mathrm{ZnCl}_{2}$ & 824 & $6 \mathrm{~mol} \mathrm{~L}^{-1} \mathrm{KOH}$ & $171^{d}$ & 20.8 & 0.500 & $\mathrm{~S}(40)$ \\
\hline PANI & $\mathrm{KOH}$ & 2287 & $6 \mathrm{~mol} \mathrm{~L}^{-1} \mathrm{KOH}$ & $220^{d}$ & 9.6 & 0.500 & $S(41)$ \\
\hline PNPEA & $\mathrm{ZnCl} / 2 / \mathrm{H}_{2} \mathrm{SO}_{4}-\mathrm{HNO}_{3}$ & 760 & $1 \mathrm{~mol} \mathrm{~L}^{-1} \mathrm{H}_{2} \mathrm{SO}_{4}$ & $370^{c}$ & 48.7 & 0.500 & Our work \\
\hline PANI & $\mathrm{ZnCl}_{2} / \mathrm{H}_{2} \mathrm{SO}_{4}-\mathrm{HNO}_{3}$ & 732 & $1 \mathrm{~mol} \mathrm{~L}^{-1} \mathrm{H}_{2} \mathrm{SO}_{4}$ & $360^{c}$ & 49.2 & 0.500 & Our work \\
\hline
\end{tabular}

${ }^{a}$ Mass specific capacitance; ${ }^{b}$ Area-specific capacitance that normalized to BET surface area; ${ }^{c}$ Values of capacitance for the threeelectrode cell system; ${ }^{d}$ Values of capacitance for the two-electrode cell system. 
Table 44 Comparison of EIS Parameters of Reported Different Carbon Sources.

\begin{tabular}{|c|c|c|c|c|c|c|c|c|c|c|}
\hline Sample & $\begin{array}{c}\text { Raw } \\
\text { materials }\end{array}$ & $\begin{array}{l}\text { Activated } \\
\text { method }\end{array}$ & $\begin{array}{c}\mathrm{R}_{\mathrm{s}} \\
\left(\mathrm{cm}^{-2}\right)\end{array}$ & $\begin{array}{c}\mathrm{R}_{\mathrm{ct}} \\
\left(\mathrm{cm}^{-2}\right)\end{array}$ & $\begin{array}{c}\mathrm{R}_{\mathrm{p}} \\
\left(\mathrm{cm}^{-2}\right)\end{array}$ & $\begin{array}{c}\mathrm{S}_{\mathrm{BET}} \\
\left(\mathrm{m}^{2} \mathrm{~g}^{-1}\right)\end{array}$ & $\begin{array}{c}\mathrm{C}_{\mathrm{g}} \\
\left(\mathrm{F} \mathrm{g}^{-1}\right)\end{array}$ & $\begin{array}{c}\mathrm{C}_{\mathrm{s}} \\
\left(\mathrm{F} \mathrm{cm}^{-2}\right)\end{array}$ & Electrolyte & Reference \\
\hline MMPGC & $\mathrm{PFA}^{1)}$ & Soft template & $0.28^{2)}$ & $1.04^{2)}$ & $0.95^{2)}$ & 340 & - & - & $2 \mathrm{~mol} \mathrm{~L}^{-1} \mathrm{H}_{2} \mathrm{SO}_{4}$ & $\left(\mathrm{~S}_{5}\right)$ \\
\hline Ac-35 & $\mathrm{PEC}^{3)}$ & $\mathrm{KOH}$ & $0.06^{4)}$ & $0.34^{4)}$ & $\mathrm{O}^{4)}$ & 2312 & $34^{25)}$ & $14.8^{5)}$ & $6 \mathrm{~mol} \mathrm{~L}^{-1} \mathrm{KOH}$ & $\left(\mathrm{S}_{42}\right)$ \\
\hline C-So & PFA & Hard template & $1.01^{6)}$ & $0.97^{6)}$ & - & 592 & 717) & $12.0^{7)}$ & $1 \mathrm{~mol} \mathrm{~L}^{-1} \mathrm{KOH}$ & $\left(\mathrm{S}_{43}\right)$ \\
\hline $\mathrm{ACM}_{5}$ & $\mathrm{RWSD}^{8)}$ & $\mathrm{CO}_{2}$ & $0.48^{9)}$ & $0.49^{9)}$ & - & 912 & $138^{10)}$ & $15.1^{10)}$ & $1 \mathrm{~mol} \mathrm{~L}^{-1} \mathrm{H}_{2} \mathrm{SO}_{4}$ & $\left(\mathrm{~S}_{44}\right)$ \\
\hline carbon fiber & PAN $^{11)}$ & Woven cloth & $1.6^{12)}$ & $0.97^{12)}$ & $0.32^{12)}$ & 1200 & $128^{13)}$ & $10.7^{13)}$ & $2 \mathrm{~mol} \mathrm{~L}^{-1} \mathrm{H}_{2} \mathrm{SO}_{4}$ & $\left(\mathrm{~S}_{45}\right)$ \\
\hline NHPC-8oo & $\mathrm{PAPF}^{14)}$ & Hard template & $0.11^{15)}$ & $1.01^{15)}$ & - & 1542 & $242^{16)}$ & $15 \cdot 7^{16)}$ & $6 \mathrm{~mol} \mathrm{~L}^{-1} \mathrm{KOH}$ & $\left(\mathrm{S}_{46}\right)$ \\
\hline AC-8oo & $\mathrm{WCs}^{17)}$ & $\mathrm{KOH}$ & $0.5^{18)}$ & $\sim 1.0^{18)}$ & - & 1586 & $340^{19)}$ & $21.4^{19)}$ & $6 \mathrm{~mol} \mathrm{~L}{ }^{-1} \mathrm{KOH}$ & $\left(\mathrm{S}_{47}\right)$ \\
\hline $\mathrm{a}-\mathrm{PFC}_{3}$ & $\mathrm{PF}^{20)}$ & $\mathrm{KOH}$ & $2.91^{21)}$ & $0.93^{21)}$ & - & 1159 & $324^{22)}$ & $28.0^{22)}$ & $1 \mathrm{~mol} \mathrm{~L}^{-1} \mathrm{H}_{2} \mathrm{SO}_{4}$ & $\left(\mathrm{~S}_{48}\right)$ \\
\hline$A C-700$ & $\mathrm{PANI}^{23)}$ & $\mathrm{O}_{2}$ & $1.3^{24)}$ & $0.4^{24)}$ & - & 618 & $210^{25)}$ & $34.0^{25)}$ & $6 \mathrm{~mol} \mathrm{~L}^{-1} \mathrm{KOH}$ & $\left(\mathrm{S}_{49}\right)$ \\
\hline CA & PANI & $\mathrm{K}_{2} \mathrm{CO}_{3}$ & $1.53^{26)}$ & $0.45^{26)}$ & - & 917 & $210^{27)}$ & $22.9^{27)}$ & $6 \mathrm{~mol} \mathrm{~L}^{-1} \mathrm{KOH}$ & $\left(\mathrm{S}_{50}\right)$ \\
\hline PEA-Zn-70o-40 & PNPEA $^{28)}$ & $\mathrm{ZnCl}_{2}$ & $0.97^{29)}$ & $0.27^{29)}$ & $0.04^{29)}$ & 760 & $370^{30)}$ & $48.7^{30)}$ & $1 \mathrm{~mol} \mathrm{~L}^{-1} \mathrm{H}_{2} \mathrm{SO}_{4}$ & This work \\
\hline
\end{tabular}

1) Polyfurfuryl alcohol; ${ }^{2)}$ Reference 600 (Gamry Instrument, USA), three-electrode system.

3) Petroleum coke; ${ }^{4)} \mathrm{CHI}-760 \mathrm{C}$ (China), two-electrode system; ${ }^{5)}$ Data collected at current density of o.05 $\mathrm{A} \mathrm{g} \mathrm{g}^{-1}, \mathrm{C}_{\mathrm{s}}=\mathrm{C}_{\mathrm{g}} / \mathrm{S}_{\mathrm{BET}}$.

6) Solartron 1287, three -electrode system; ${ }^{7)}$ Data collected at scan rate of $\mathrm{t} 5 \mathrm{mV} \mathrm{s}{ }^{-1}, \mathrm{C}_{\mathrm{s}}=\mathrm{C}_{\mathrm{g}} / \mathrm{S}_{\mathrm{BET}}$.

${ }^{8)}$ Rubber wood sawdust; ${ }^{9)}$ Solartron 1286, two-electrode system; ${ }^{10)}$ Data collected at current density of o.o1 $\mathrm{A} \mathrm{cm}^{-2}, \mathrm{C}_{\mathrm{s}}=\mathrm{C}_{\mathrm{g}} / \mathrm{S}_{\mathrm{BET}}$.

${ }^{11)}$ Polyacrylonitrile; ${ }^{12)}$ two-electrode system; ${ }^{13)}$ Data collected at current density of $0.001 \mathrm{~A} \mathrm{~cm}^{-2}, \mathrm{C}_{\mathrm{s}}=\mathrm{C}_{\mathrm{g}} / \mathrm{S}_{\mathrm{BET}}$. 
14) a condensation polymer between m-aminophenol and formalin; ${ }^{15)}$ Chi66oD, three-electrode system; ${ }^{16)}$ Data collected at current density of $0.2 \mathrm{~A} \mathrm{~g}^{-1}, \mathrm{C}_{\mathrm{s}}=\mathrm{C}_{\mathrm{g}} / \mathrm{S}_{\mathrm{BET}}$.

${ }^{17)}$ Willow catkins; ${ }^{18)}$ Chi66oC, three-electrode system; ${ }^{19)}$ Data collected at current density of o.1 $\mathrm{A} \mathrm{g} \mathrm{g}^{-1}, \mathrm{C}_{\mathrm{s}}=\mathrm{C}_{\mathrm{g}} / \mathrm{S}_{\mathrm{BET}}$.

${ }^{20)}$ Paulownia flower; ${ }^{21)}$ Chi66oD, two-electrode system; ${ }^{22)}$ Data collected at current density of o.5 $\mathrm{A} \mathrm{g} \mathrm{g}^{-1}, \mathrm{C}_{\mathrm{s}}=\mathrm{C}_{\mathrm{g}} / \mathrm{S}_{\mathrm{BET}}$.

${ }^{23)}$ Polyaniline; ${ }^{24)}$ Chi66oA, two-electrode system; ${ }^{25)}$ Data collected at current density of o.5 A g $\mathrm{g}^{-1}, \mathrm{C}_{\mathrm{s}}=\mathrm{C}_{\mathrm{g}} / \mathrm{S}_{\mathrm{BET}}$.

26) Chi66oA, two-electrode system; ${ }^{27)}$ Data collected at scan rate of $2 \mathrm{mV} \mathrm{s}{ }^{-1}, \mathrm{C}_{\mathrm{s}}=\mathrm{C}_{\mathrm{g}} / \mathrm{S}_{\mathrm{BET}}$.

${ }^{28)}$ Poly (N-phenylethanolamine); ${ }^{29)}$ Solartron 1287, three-electrode system; ${ }^{30)}$ Data collected at current density of $0.5 \mathrm{~A} \mathrm{~g}^{-1}, \mathrm{C}_{\mathrm{s}}=\mathrm{C}_{\mathrm{g}} / \mathrm{S}_{\mathrm{BET}}$. 


\section{REFERENCES:}

(S1) Puthusseri, D.; Aravindan, V.; Madhavi, S.; Ogale, S. 3D Micro-Porous Conducting Carbon Beehive by Single Step Polymer Carbonization for High Performance Supercapacitors: the Magic of in Situ Porogen Formation. Energy Environ. Sci. 2014, 7, 728-735.

(S2) Candelaria, S. L.; Garcia, B. B.; Liu, D.; Cao, G. Nitrogen Modification of Highly Porous Carbon for Improved Supercapacitor Performance. J. Mater. Chem. 2012, 22, 9884-9889.

(S3) Rufford, T. E.; Hulicova-Jurcakova, D.; Khosla, K.; Zhu, Z.; Lu, G. Q. Microstructure and Electrochemical Double-Layer Capacitance of Carbon Electrodes Prepared by Zinc Chloride Activation of Sugar Cane Bagasse. J. Power Sources 2010, 195, 912-918.

(S4) Huang, C.-W.; Hsieh, C.-T.; Kuo, P.-L.; Teng, H. Electric Double Layer Capacitors Based on a Composite Electrode of Activated Mesophase Pitch and Carbon Nanotubes. J. Mater. Chem. 2012, 22, 7314-7322.

(S5) Mun, Y.; Jo, C.; Hyeon, T.; Lee, J.; Ha, K.-S.; Jun, K.-W.; Lee, S.-H.; Hong, S.-W.; Lee, H. I.; Yoon, S.; Lee, J. Simple Synthesis of Hierarchically Structured Partially Graphitized Carbon by Emulsion/Block-Copolymer Co-template Method for High Power Supercapacitors. Carbon 2013, 64, 391-402.

(S6) Liu, X.; Juan, L.; Zhan, L.; Tang, L.; Wang, Y.; Qiao, W.; Liang, X.; Ling, L. Effect of Conductive Filler on the Impedance Behaviors of Activated Carbon Based Electric Double Layer Capacitors. J. Electroanal. Chem. 2010, 642, 75-81.

(S7) Aboutalebi, S. H.; Chidembo, A. T.; Salari, M.; Konstantinov, K.; Wexler, D.; Liu, H. K.; Dou, S. X. Comparison of GO, GO/MWCNTs Composite and MWCNTs as Potential Electrode Materials for Supercapacitors. Energy Environ. Sci. 2011, 4, 1855-1865.

(S8) He, X.; Ling, P.; Yu, M.; Wang, X.; Zhang X.; Zheng, M. Rice Husk-Derived Porous Carbons with High Capacitance by ZnCl2 Activation for Supercapacitors. Electrochim. Acta 2013, 105, 635-641.

(S9) Badawy, W. A.; Ismail, K. M.; Khalifa, Z. M. Conducting Poly(N-(1-Naphthyl) Ethylene-Diamine Dihydrochloride) Electropolymerization, Characterization and Electroanalytical Applications. J. Appl. Electrochem. 20o7, 37, $593-604$.

(S1o) Yağan, A.; Pekmez, N. Ö.; Yildiz, A. Investigation of Protective Effect of Poly(N-ethylaniline) Coatings on Iron in Various Corrosive Solutions. Surf. Coat. Technol. 2007, 201, 7339-7345.

(S11) Yuan, D.-S.; Zhou, T.-X.; Zhou, S.-L.; Zou, W.-J.; Mo, S.-S.; Xia, N.-N. Nitrogen-Enriched Carbon Nanowires from the Direct Carbonization of Polyaniline Nanowires and Its Electrochemical Properties. Electrochem. Commun. 2011, 13, $242-246$.

(S12) Nabid, M. R.; Taheri, S. S.; Sedghi, R.; Entezami, A. A. Chemical Synthesis and Characterization of Watersoluble, Conducting Poly (N-phenylglycine). Iran. Polym. J. 20o8, 17, 365-371.

(S13) Yağan, A.; Pekmez, N. Ö.; Yildiz, A. Electrochemical Synthesis of Poly(N-methylaniline) on an Iron Electrode and Its Corrosion Performance. Electrochim. Acta 20o8, 53, 5242-5251.

(S14) Sivakumar, R.; Saraswathi, R. Redox Properties of Poly(N-methylaniline). Synth. Met. 2003, 138, 381-390.

(S15) Bazuła, P. A.; Lu, A. H.; Nitz, J. J.; Schüth, F. Surface and Pore Structure Modification of Ordered Mesoporous Carbons via a Chemical Oxidation Approach. Microporous Mesoporous Mater. 2008, 108, 266-275.

(S16) Vujković, M.; Gavrilov, N.; Pašti, I.; Krstić, J.; Travas-Sejdic, J.; Ćirić-Marjanović, G.; Mentus, S. Superior Capacitive and Electrocatalytic Properties of Carbonized Nanostructured Polyaniline Upon a Low-Temperature Hydrothermal Treatment. Carbon 2013, $64,472-486$.

(S17) Rozlívková, Z.; Trchová, M.; Exnerová, M.; Stejskal, J. The Carbonization of Granular Polyaniline to Produce NitrogenContaining Carbon. Synth. Met. 2011, 161, 1122-1129.

(S18) Trchová, M.; Matějka, P.; Brodinová, J.; Kalendová, A.; Prokeš, J.; Stejskal, J. Structural and Conductivity Changes During the Pyrolysis of Polyaniline Base. Polym. Degrad. Stab. 20o6, 91, 114-121.

(S19) Cataldo, F.; Maltese, P. Synthesis of Alkyl and N-Alkyl-Substituted Polyanilines: A Study on Their Spectral Properties and Thermal Stability. Eur. Polym. J. 2002, 38, 1791-1803.

(S20) Bhadra, S.; Khastgir, D. Extrinsic and Intrinsic Structural Change During Heat Treatment of Polyaniline. Polym. Degrad. Stab. 2008, 93, 1094-1099. 
(S21) Chen, C.-H. Thermal Studies of Polyaniline Doped with Dodecyl Benzene Sulfonic Acid Directly Prepared via Aqueous Dispersions. J. Polym. Res. 2002, 9, 195-200.

(S22) Ho, K.-S.; Han, Y.-K.; Tuan, Y.-T.; Huang, Y.-J.; Wang, Y.-Z.; Ho, T.-H.; Hsieh, T.-H.; Lin, J.-J.; Lin, S.-C. Formation and Degradation Mechanism of a Novel Nanofibrous Polyaniline. Synth. Met. 2009, 159, 1202-1209.

(S23) Chen, T.; Dong, C.; Li, X.; Gao, J. Thermal Degradation Mechanism of Dodecylbenzene Sulfonic Acid-Hydrochloric Acid Codoped Polyaniline. Polym. Degrad. Stab. 2009, 94, 1788-1794.

(S24) Luo, K.; Shi, N.; Sun, C. Thermal Transition of Electrochemically Synthesized Polyaniline. Polym. Degrad. Stab. 20o6, 91, 266o2664 .

(S25) Pedley, J. B.; Naylor, R. D.; Kirby, S. P. Thermochemical data of organic compounds 2nd ed; Chapman and Hall: New York, 1986.

(S26) MacFaul, P. A.; Wayner, D. D. M.; Ingold, K. U. Measurement of N-H Bond Strengths in Aromatic Amines by Photoacoustic Calorimetry. J. Org. Chem. 1997, 62, 3413-3414.

(S27) Hulicova-Jurcakova, D.; Seredych, M.; Lu, G. Q.; Bandosz, T. J. Combined Effect of Nitrogen- and Oxygen-Containing Functional Groups of Microporous Activated Carbon on its Electrochemical Performance in Supercapacitors. Adv. Funct. Mater. 2oog, $19,438-447$.

(S28) Jin, H.; Wang, X.; Gu, Z.; Polin, J. Carbon Materials from High Ash Biochar for Supercapacitor and Improvement of Capacitance with $\mathrm{HNO}_{3}$ Surface Oxidation. J. Power Sources 2013, 236, 285-292.

(S29) Li, Z.; Xu, H.; Tan, X.; Wang, H.; Holt, C. M. B.; Stephenson, T.; Olsen, B. C.; Mitlin, D. Mesoporous Nitrogen-Rich Carbons Derived From Protein for Ultra-High Capacity Battery Anodes and Supercapacitors. Energy Environ. Sci. 2013, 6, 871-878.

(S3o) Zhao, Y.; Ran, W.; He, J.; Song, Y. F.; Zhang, C.; Xiong, D.-B.; Gao, F.; Wu, J.; Xia, Y. Oxygen-Rich Hierarchical Porous Carbon Derived from Artemia Cyst Shells with Superior Electrochemical Performance. ACS Appl. Mater. Interfaces 2015, 7, 1132-1139.

(S31) Rufford, T. E.; Hulicova-Jurcakova, D.; Zhu, Z.; Lu, G. Q. Nanoporous Carbon Electrode from Waste Coffee Beans for High Performance Supercapacitors. Electrochem. Commun. 2008, 10, 1594-1597.

(S32) Elmouwahidi, A.; Zapata-Benabithe, Z.; Carrasco-Marín, F.; Moreno-Castilla, C. Activated Carbons from KOH-Activation of Argan (Argania Spinosa) Seed Shells as Supercapacitor Electrodes. Bioresour. Technol. 2012, 111, 185-190.

(S33) Biswal, M.; Banerjee, A.; Deo, M.; Ogale, S. From Dead Leaves to High Energy Density Supercapacitors. Energy Environ. Sci. 2o13, 6, 1249-1259.

(S34) Wei, J.-S.; Ding, H.; Wang, Y.-G.; Xiong, H.-M. Hierarchical Porous Carbon Materials with High Capacitance Derived from Schiff-Base Networks. ACS Appl. Mater. Interfaces 2015, 7, 5811-5819.

(S35) Ruiz, V.; Blanco, C.; Santamaría, R.; Ramos-Fernández, J. M.; Martínez-Escandell, M.; Sepúlveda-Escribano, A.; RodríguezReinoso, F. An Activated Carbon Monolith as an Electrode Material for Supercapacitors. Carbon 2009, 47, $195-200$.

(S36) Babel, K.; Jurewicz, K. KOH Activated Carbon Fabrics as Supercapacitor Material. J. Phys. Chem. Solids 2004, 65, 275-280.

(S37) Seredych, M.; Hulicova-Jurcakova, D.; Lu, G. Q.; Bandosz, T. J. Surface Functional Groups of Carbons and the Effects of Their Chemical Character, Density and Accessibility to Ions on Electrochemical Performance. Carbon 2oo8, 46, 1475-1488.

(S38) Ania, C. O.; Khomenko, V.; Raymundo-Piñero, E.; Parra, J. B.; Béguin, F. The Large Electrochemical Capacitance of Microporous Doped Carbon Obtained by Using a Zeolite Template. Adv. Funct. Mater. 2007, 17, 1828-1836.

(S39) Zhang, J.; Gong, L.; Sun, K.; Jiang, J.; Zhang, X. Preparation of Activated Carbon from Waste Camellia Oleifera Shell for Supercapacitor Application. J. Solid State Electrochem. 2012, 16, 2179-2186.

(S40) Xiang, X.; Liu, E.; Huang, Z.; Shen, H.; Tian, Y.; Xiao, C.; Yang, J.; Mao, Z. Preparation of Activated Carbon from Polyaniline by Zinc Chloride Activation as Supercapacitor Electrodes. J. Solid State Electrochem. 2011, 15, 2667-2674.

(S41) Li, L.; Liu, E.; Shen, H.; Yang, Y.; Huang, Z.; Xiang, X.; Tian, Y. Charge Storage Performance of Doped Carbons Prepared from Polyaniline for Supercapacitors. J. Solid State Electrochem. 2011, 15, 175-182.

(S42) He, X.; Geng, Y.; Qiu, J.; Zheng, M.; Long, S.; Zhang, X. Effect of Activation Time on the Properties of Activated Carbons Prepared by Microwave-Assisted Activation for Electric Double Layer Capacitors. Carbon 2010, 48, 1662-1669. 
(S43) Yang, C.; Li, C-Y. V.; Li, F.; Chan, K.-Y. Complex Impedance with Transmission Line Model and Complex Capacitance Analysis of Ion Transport and Accumulation in Hierarchical Core-Shell Porous Carbons. J. Electrochem. Soc. 2013, 16o, H271-H278.

(S44) Taer, E.; Deraman, M.; Talib, I. A.; Awitdrus, A.; Hashmi, S. A.; Umar, A. A. Preparation of a Highly Porous Binderless Activated Carbon Monolith from Rubber Wood Sawdust by a Multi-Step Activation Process for Application in Supercapacitors. Int. J. Electrochem. Sci. 2011, 6, 3301-3315.

(S45) Huang, C.-W.; Chuang, C.-M.; Ting, J.-M.; Teng, H. Significantly Enhanced Charge Conduction in Electric Double Layer Capacitors Using Carbon Nanotube-Grafted Activated Carbon Electrodes. J. Power Sources 2oo8, 183, 406-410.

(S46) Zhou, J.; Zhang, Z.; Xing, W.; Yu, J.; Han, G.; Si, W.; Zhuo, S. Nitrogen-Doped Hierarchical Porous Carbon Materials Prepared from Meta-Aminophenol Formaldehyde Resin for Supercapacitor with High Rate Performance. Electrochim. Acta 2015, 153, 68-75.

(S47) Wang, K.; Zhao, N.; Lei, S.; Yan, R.; Tian, X.; Wang, J.; Song, Y.; Xu, D.; Guo, Q.; Liu, L. Promising Biomass-Based Activated Carbons Derived from Willow Catkins for High Performance Supercapacitors. Electrochim. Acta 2015, 166, 1-11.

(S48) Chang, J.; Gao, Z.; Wang, X.; Wu, D.; Xua, F.; Wang, X.; Guo, Y.; Jiang, K. Activated Porous Carbon Prepared from Paulownia Flower for High Performance Supercapacitor Electrodes. Electrochim. Acta 2015, 157, 290-298.

(S49) Xiang, X.; Liu, E.; Wu, Y.; Tian, Y.; Xie, H.; Wu, Z.; Zhu, Y. Nitrogen- and Oxygen-Enriched Carbon with Square Tubular Structure Prepared from Polyaniline as Electrode for Supercapacitors. Fuel Cell 2012, 12, 892-897.

(S50) Xiang, X.; Liu, E.; Li, L.; Yang, Y.; Shen, H.; Huang, Z.; Tian, Y. Activated Carbon Prepared from Polyaniline Base by $\mathrm{K}_{2} \mathrm{CO}_{3}$ Activation for Application in Supercapacitor Electrodes. J. Solid State Electrochem. 2011, 15, 579-585. 